SEP 28 39948

ENGINEERING DATA TRANSMITTAL Lta. 21

Page 1 of 1

1. EDT 604972

\begin{tabular}{|l|l|}
\hline $\begin{array}{l}\text { 2. To: (Receiving Organization) } \\
\text { Distribution }\end{array}$ & $\begin{array}{l}\text { 3. From: Coriginating Organization } \\
\text { Mechanical Equipment }\end{array}$ \\
\hline 5. Proj./Prog./Dept./Div.: & 6. Cog. Engr.: \\
Ferrocyanide. Tanks & K. L. Morris/7EA30/N2C4K
\end{tabular}

8. Originator Remarks:

Release test report.
11. Receiver Remarks:

4. Related EDT No.:
NA
$\begin{gathered}\text { 7. Purchase Order No.: } \\ \text { NA }\end{gathered}$

9. Equip./Component No.:

NA

10. System/Bldg./Facility:

IR Camera System

12. Major Assm. Dwg. No.:

NA

13. Permit/Permit Application No.: NA

14. Required Response Date:

September 30, 1994

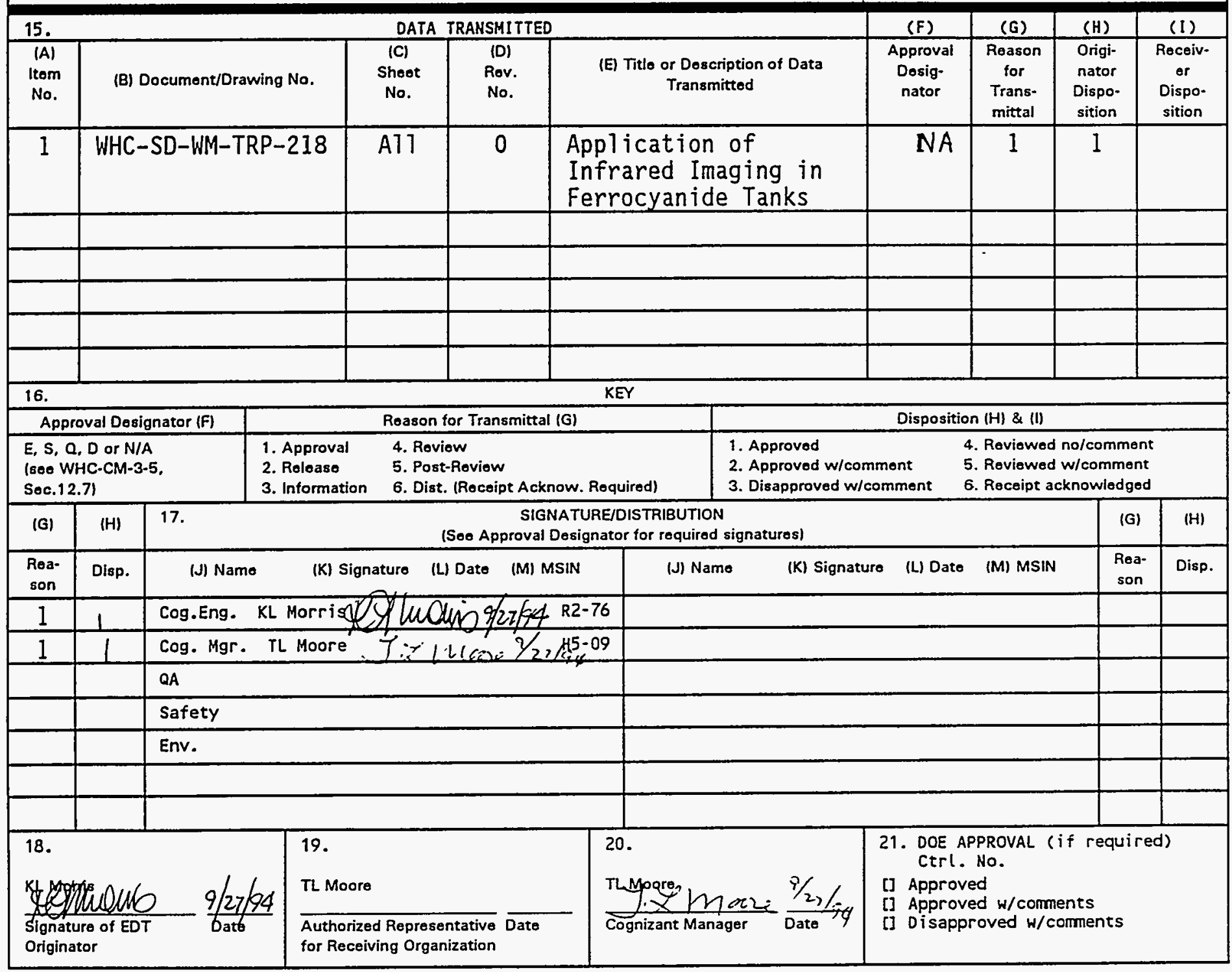




\section{RELEASE AUTHORIZATION}

Document Number: WHC-SD-WM-TRP-218, Rev.0

Document Title: Application of Infrared Imaging in Ferrocyanide Tanks

Release Date: $\quad$ September 27, 1994

This document was reviewed following the procedures described in WHC-CM-3-4 and is:

APPROVED FOR PUBLIC RELEASE

$* * * * * * * * * * * *$

WHC Information Release Administration Specialist:

U. W. poerthand v.L. BIRKLAND (Signature)

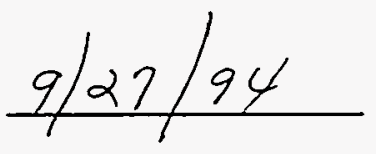

(Date) 


\section{DISCLAIMER}

Portions of this document may be illegible in electronic image products. Images are produced from the best available original document. 
2. Title

Application of Infrared Imaging in Ferrocyanide Tanks .

5. Key Words

Infrared

Imaging

Ferrocyanide

Thermal Imaging

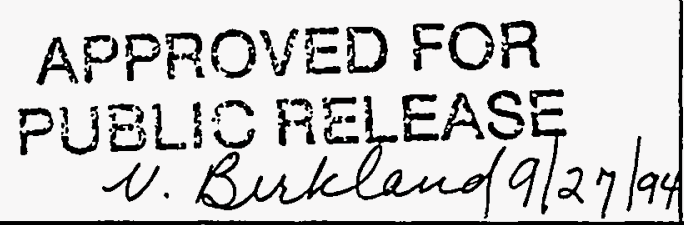

3. Number

WHC-SD-WM-TRP-218

4. Rev No.

0

6. Author

Name: $\mathrm{KL}$ Morris

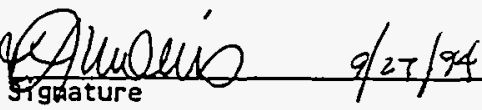

Organization/Charge code 7EA30/N2C4K

\section{Abstract}

This report describes testing done using an infrared imaging system to evaluate waste surfaces for hot spots.

8. PURPOSE AND USE OF DOCUMENT - This document was prepared for use wi thin the U.S. Department of Energy and its contractors. It is to be Used only to perform, direct, or integrate fiork under U.S. Department of Energy contracts. This document is not approved for publit release yntil reviewed.

PATENT STATUS - This document copy, since $t$ is transmitted in advance of pabnt clearance, is made available in confidence solely for use in performance of Hork under contracts with the U.S. Depactment of Energy. This document is not th be publ ished nor its contents otherhise disseminated of used for purnoses other than specifjed above befole patent approval for such release or use has been secured, upon request, from the Patent Counsel, U.S. Department of Energy Field Office, Richland, WA.

DISCLAIMER - This report was prepared as an account of work sponsored by an agency of the United States Government. Neither the United States Government nor any agency thereof, nor any of their employees, nor any of their contractors, subcontractors or their employees, makes any warranty, express or implied, or assumes any legal liability or responsibility for the accuracy, completeness, or any third party's use or the results of such use of any information, apparatus, product, or process disclosed, or represents that its use would not infringe privately owned rights. Reference herein to any specific commercial product, process, or service by trade name, trademark, manufacturer, or otherwise, does not necessarily constitute or imply its endorsement, recommendation, or favoring by the United States Government or any agency thereof or its contractors or subcontractors. The views and opinions of authors expressed herein do not necessarily state or reflect those of the United States Government or any agency thereof.

9. Impact Level NA

10. RELEASE STAMP

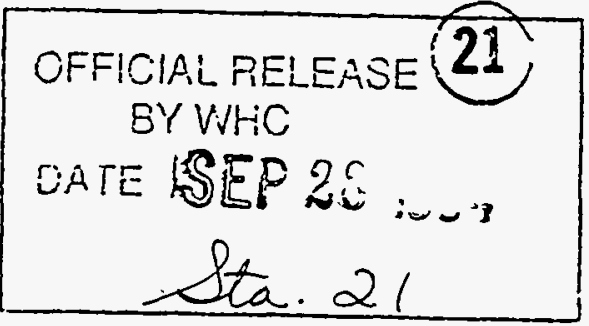


WHC-SD-WM-TRP-218

Rev. 0

APPLICATION OF INFRARED

IMAGING IN FERROCYANIDE TANKS

L. E. Efferding

R. B. Mailhot, Jr.

J. M. McLaren

K. L. Morris

September 1994 


\section{WHC-SD-WM-TRP-218}

Rev. 0

This page intentionally left blank. 
WHC-SD-WM-TRP-218

Rev. 0

\title{
APPLICATION OF INFRARED IMAGING \\ IN FERROCYANIDE TANKS
}

\author{
L. E. Efferding \\ R. B. Mailhot, Jr. \\ J. M. McLaren \\ K. L. Morris
}

\begin{abstract}
This report analyzes the feasibility of using infrared imaging techniques and scanning equipment to detect potential "hot spots" within ferrocyanide waste tanks at the Hanford Site. A hot spot is defined as a volumetric region within a waste tank with an excessively warm $\left[220^{\circ} \mathrm{C}\left(428^{\circ} \mathrm{F}\right)\right]$ temperature that is generated by radioactive isotopes. The thermal image of a hot spot was modeled by computer. This model determined the image an IR system must detect. Laboratory and field tests of the imaging system are described, and conclusions based on 7aboratory and field data are presented. The report shows that infrared imaging is capable of detecting hot spots in ferrocyanide waste tanks with depths of up to $3.94 \mathrm{~m}$ (155 in.). The infrared imaging system is a useful technology for initial evaluation and assessment of hot spots in the majority of ferrocyanide waste tanks at the Hanford Site. The system will not allow an exact hot spot and temperature determination, but it will provide the necessary information to determine the worst-case hot spot detected in temperature patterns.
\end{abstract}


WHC-SD-WM-TRP-218

Rev. 0

This page intentionally left blank. 
WHC-SD-WM-TRP-218

Rev. 0

\section{CONTENTS}

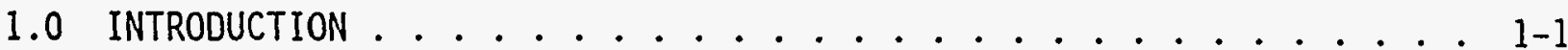

1.1 PURPOSE AND SCOPE ................... . . . . . . .

1.2 BACKGROUND . . . . . . . . . . . . . . $1-2$

1.3 SURFACE TEMPERATURE PATTERNS ............. 1-3

1.3.1 Computer Analysis of Patterns ............ 1-3

1.3.2 Limits of Hot Spot Detectability Based on Modeling ... 1-6

2.0 DESCRIPTION OF THE EQUIPMENT ............. 2-1

2.1 SCANNER ........................ 2-1

2.2 OPERATION OF THE SCANNER .............. 2-1

2.3 OPERATION OF THE IMAGE PROCESSOR ............... $2-3$

2.4 THERMAL IMAGE MANAGEMENT SYSTEM . . . . . . . . . $2-3$

2.5 INFRARED SCANNER HOUSING ASSEMBLY $\ldots \ldots . \ldots \ldots$

3.0 LABORATORY TESTS OF INFRARED IMAGING SYSTEM .......... $3-1$

3.1 CALIBRATION BY BLACK BODY STANDARD . . . . . . . . . . 3-1

3.1.1 Description of BTack Body Calibration ........ 3-1

3.1.2 Summary of BTack Body Calibration .......... 3-2

3.1.3 Results of B7ack Body Calibration ......... 3-2

3.1.4 Validation of Black Body Calibration ........ 3-2

3.1 .5 Conclusions ................... 3-2

3.2 EMISSIVITY . . . . . . . . . . . . . . . . $3-3$

3.2.1 Description ' Ef Emissivity Test . . . . . . . 3-3

3.2.2 Summary of Emissivity Test . . . . . . . . . . 3-3

3.2.3 Results of Emissivity Test . . . . . . . . . . 3-3

3.2.4 Validation of Emissivity Test . . . . . . . . . 3-3

3.2 .5 Conclusions .................... 3-5

3.3 ATMOSPHERIC ATTENUATION .................... $3-5$

3.3.1 Description of Atmospheric Attenuation Test . . . . . 3-5

3.3.2 Summary of Atmospheric Attenuation Test . . . . . . 3-5

3.3.3 Results of Atmospheric Attenuation Test ....... 3-5

3.3.4 Validation of Atmospheric Attenuation Test . . . . . 3-7

3.3.5 Conclusions .................... 3-7

3.4 GAMMA RADIATION EFFECTS . . . . . . . . . . . . 3-7

3.4.1 Description of Gamma Radiation Effects Test . . . . 3-7

3.4.2 Summary of Gamma Radiation Effects Test . . . . . . . 3-7

3.4.3 Results of Gamma Radiation Effects Test . . . . . . . . 3-7

3.4.4 Validation of Gamma Radiation Effects Test . . . . . . 3-8

3.4 .5 Conclusions ............... 3-8

3.5 AMBIENT TEMPERATURE . . . . . . . . . . . . . . 3-8

3.5.1 Description of Ambient Temperature Test . . . . . . 3-8

3.5.2 Summary of Ambient Temperature Test . . . . . . . . . 3-8

3.5.3 Results of Ambient Temperature Test . . . . . . . . 3-8

3.5.4 Validation of Ambient Temperature Test . . . . . . . 3-9

3.5.5 Conclusions ... . . . . . . . . . . . 3-9

3.6 SYSTEM PERFORMANCE UNDER IN-TANK CONDITIONS ........ 3-9

3.6.1 Description of System Performance Test . . . . . . . . . 3-9

3.6.2 Summary of System Performance Test . . . . . . . . 3-9

3.6.3 Results of System Performance Test . . . . . . . . . 3-10 
Rev. 0

\section{CONTENTS (continued)}

3.6.4 Validation of System Performance Test ....... . 3-10 3.6.5 Conclusions .................. . . . . . . . . . . . . . 3.7 ACCEPTANCE TEST . . . . . . . . . . . . . . . $3-10$ 3.7.1 Description of Acceptance Test . . . . . . . . 3-10 3.7.2 Summary of Acceptance Test . . . . . . . . . . . 3-12 3.7.3 ResuTts of Acceptance Test . . . . . . . . . . . 3-12 3.7.4 Validation of Acceptance Test . . . . . . . . . 3-13

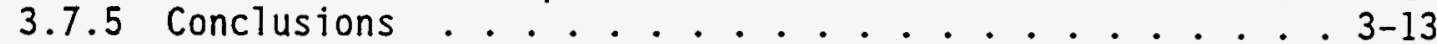
3.8 SUMMARY OF LABORATORY TESTING . . . . . . . . . . . 3-13

4.0 FIELD TEST OF INFRARED IMAGING SYSTEM ............ . . . 4.1 DESCRIPTION OF TEST IN TANK $241-S-110 \ldots \ldots \ldots . . \ldots$. . . . . 4.2 SUMMARY OF TEST IN TANK $241-S-110 \ldots \ldots$. $\ldots . . . . . . . . .4$ 4.3 RESULTS AND OBSERVATIONS OF TEST IN TANK 241-S-110 . . . . . 4-4 4.4 VALIDATION OF TEST IN TANK $241-S-110 \ldots \ldots . . . . . . .44$ 4.5 CONCLUSIONS OF TANK $241-S-110$ TEST $\ldots \ldots . . . . . .44$

5.0 SUMMARY . . . . . . . . . . . . . . . . . 5-1 5.1 OBSERVATIONS AND RESULTS ............ . . 5-1

5.2 CONCLUSIONS AND RECOMMENDATIONS ............ . 5-1

6.0 REFERENCES ....................... . . . . . . . . 
WHC-SD-WM-TRP-218

Rev. 0

\section{LIST OF FIGURES}

1-1. Computer Analysis Modeled on 241-BY-104 for a Hot Spot

Nine Inches Below the Surface ................ . 1-4

1-2. Computer Analysis Modeled on 241-BY-104 for a Hot Spot

on the Tank Bottom ................. . . . 1-5

2-1. Infrared Scanner System . . . . . . . . . . . . . . . 2-2

2-2. Color-Enhanced Scan Data (Example) . . . . . . . . . . . 2-4

2-3. Infrared Scanner Installation . . . . . . . . . . . 2-5

2-4. Infrared Scanner Control Schematic . . . . . . . . . . . 2-6

2-5. Drawing $\mathrm{H}-2-81787$. . . . . . . . . . . . . . . . 2-7

3-1. Emissivity at Varying Angles of Incidence . . . . . . . . . . . 3-4

3-2. Temperature Loss Calculated in Ferrocyanide Tanks . . . . . . . . 3-6

3-3. A Thermogram of the Test Waste Simulations

at the $60^{\circ}$ Angle of Incidence . . . . . . . . . . . . . . 3-11

4-1. Placement of Infrared Scanner in Tank 241-S-110 . . . . . . . . 4-2

4-2. Scanned Areas of Tank 241-S-110.................. . . 4-3

4-3. Thermogram of Tank 241-S-110 . . . . . . . . . . . . . . . 4-5

4-4. Color-Enhanced Thermogram of Tank 241-S-110......... . . 4-7

\section{LIST OF TABLES}

1-1. Ferrocyanide Tanks . . . . . . . . . . . . . . . 1-2

1-2. Deepest Ferrocyanide Tanks . . . . . . . . . . . . . . . . 1-6

3-1. Calibration of Infrared Scanner . . . . . . . . . . . . 3-12

4-1. Summary of System Performance . . . . . . . . . . . . . . . . . . 4-4

4-2. Thermocouple Reading of Waste . . . . . . . . . . . . . . . 4-9 


\title{
WHC-SD-WM-TRP-218 \\ Rev. 0
}

\section{ACRONYMS}

ALARA
FIC
FLIR
FSI
FY
HCMOS
IR
ITS
LOW
PNL
R
RH
RTD
TC
TIMS
WHC

\author{
As Low As Reasonably Achievable \\ Food Instrument Corporation \\ Forward Looking Infrared \\ FLIR Systems, Inc. \\ Fiscal Year \\ Hybrid Complementary Metal Oxide Semiconductor \\ Infrared \\ In-Tank Solidification \\ Liquid Observation Well \\ Pacific Northwest Laboratory \\ Roentgen \\ Relative Humidity \\ Resistance Thermometer Detector \\ Thermocouple \\ Thermal Image Management System \\ Westinghouse Hanford Company
}


WHC-SD-WM-TRP-218

Rev. 0

\section{GLOSSARY}

ALARA--As Low As Reasonably Achievable. This refers to minimizing exposure to dangerous materials.

Angle of Incidence--The angle between the normal (to the surface) and the optic axis of the IR scanner.

Attenuation--A reduction in signal strength as caused by absorption in a medium or component. In this report, the amount of attenuation is expressed in degrees of difference between the IR scanner readings and the actual temperature.

Black Body--An ideal source of radiation (usually associated with IR radiation) in which the wavelength distribution is dependent only upon its temperature in accordance with Planck's radiation law.

Confidence Limit--The limit that has a specified probability of containing a given parameter or characteristic. In this report the probability is expressed in units of sigma (the argument of the normal distribution function).

Decontaminated--This refers to the areas where radioactive material has been removed to the level specified in WHC-CM-4-10 (see Section 6.0).

Emissivity--The property of a radiation-emitting body. The ratio of the energy emitted per unit area of the body is compared to that of a black body of the same temperature.

Ferrocyanide Tanks--The classification of Hanford Site waste tanks containing material of certain chemical properties (see Hanlon, 1992, in Section 6.0 for classification categories).

FIC Tape--The sensor element of a level detection device used on waste tanks. FIC (an abbreviation) is the trade name of the liquid level detector manufactured by Food Instrument Corporation.

HCMOS--Hybrid Complementary Metal 0xide Semiconductor. This is a type of integrated semiconductor "chip."

Hot Spot--A volumetric region within the waste volume that is excessively warm. Heat would be generated internally from radioisotopes.

Hygroscopic--The property of a material to absorb and hold water.

Infrared Scanning--The process used to measure infrared radiation emitted by object(s) sequentially and systematically in a pattern of 1 ines for the purpose of forming an infrared (IR) image.

Infrared Imaging--Graphical presentation of the measurements of IR radiation in the form of a map that correlates an object's surface temperature with its image. 
WHC-SD-WM-TRP-218

Rev. 0

Ionizing Radiation--Particles or photons that have sufficient energy to produce ionization directly in their passage through a substance.

Isotherm--The path on a thermal map or IR image along which the temperature is constant.

Leve1 of Temperature--The bottom of the temperature range on the IR Scanner, which is one of the controls on the IR Image Processor.

Liquid Observation We11 (LOW)--A closed-end, fiber-glass pipe installed into the waste to accommodate insertion of sensing probes.

LOWTRAN 7--An Air Force Geophysics Laboratory computer program that calculates IR attenuation in different atmospheres.

Pan and Tilt--This refers to the rotation of the IR scanner optic axis horizontally and vertically.

Peltier Cooler--A type of solid state refrigeration device where passage of an electrical current across a boundary of two materials causes the absorption of heat.

Purge Gas--The flow of gas (nitrogen) introduced into the special contamination control and handling housing to c0ol equipment and to pressurize the housing interior in order to prevent infusion of radioactive contaminants.

Radiometric--This relates to the measurement of electromagnetic radiation. The main applications are in the visible and near-visible portions of the electromagnetic spectrum, from about 0.1 to about 1000 micrometers.

RTD--A resistance temperature detector, which is a temperature-sensing component.

SI Units--Metric system designations (Systeme International d'Unites).

Temperature Accuracy--The error in the temperature reading obtained with the IR scanner, as compared with an accurate thermometer.

Temperature Sensitivity--The minimum resolvable temperature difference within the IR scanner field of view at a given ambient temperature and object surface temperature range.

Thermal Conductivity--The constant, $k$, is a characteristic of a material which repeats the energy per unit time and area passed through a barrier of unit Tength and unit temperature change. The units are in $\mathrm{W} / \mathrm{m}-{ }^{\circ} \mathrm{C}\left(\mathrm{BTU} / \mathrm{hr}-\mathrm{ft}-{ }^{\circ} \mathrm{F}\right)$.

Thermocouple Tree (TC Tree)--An in-tank instrument utilizing an array of thermocouples mounted in a pipe that can be installed in a waste tank to measure waste temperatures at different levels.

Thermogram Thermal Map--A graphic image on which the surface temperature of an object is displayed. 
WHC-SD-WM-TRP-218

Rev. 0

Urea Simulant--Urea fertilizer that is mixed with sugar and sufficient water to obtain the consistency of wet concrete; this simulant is used to simulate wet saltcake.

Watchlist Tanks--The category of Hanford Site waste tanks that have been identified in accordance with Pub7ic Law 101-510, Section 3137, Safety Measures for Waste Tanks at Hanford Nuclear Reservation (1990). These tanks are identified as Priority 1 Hanford Site Tank Farm Safety Issues. Priority 1 issues are those that potentially could lead to worker (onsite) or offsite radiation exposure through an uncontrolled release of fission products. 
WHC-SD-WM-TRP-218

Rev. 0

This page intentionally left blank. 
WHC-SD-WM-TRP-218

Rev. 0

\section{APPLICATION OF INFRARED IMAGING \\ IN FERROCYANIDE TANKS}

\subsection{INTRODUCTION}

\subsection{PURPOSE AND SCOPE}

The purpose of this report is to demonstrate the potential applicability of infrared (IR) imaging technology to ferrocyanide waste tanks at the Hanford Site. To support this purpose the report provides (1) background information on Hanford Site ferrocyanide waste tanks; (2) a description of the hot spot modeling analys is that determined the thermal image the IR system should find; (3) an overview of the IR imaging technology used (including equipment descriptions); (4) descriptions of Hanford Site laboratory and field tests of IR imaging technology; and (5) conclusions and recommendations regarding the applicability of IR imaging technology to Hanford Site ferrocyanide waste tanks.

The scope of this report is to characterize the performance of IR imaging technology in simulated waste tank conditions, with the intent to use IR imaging to detect hot spots within waste tanks. The scope of the report also includes the following.

- Describing the operation of an IR imaging system in a non-Watchlist tank (241-S-110).

- Demonstrating that an IR imaging system will measure surface temperatures in a tank and can identify temperature contours to within $\pm 0.28^{\circ} \mathrm{C}\left( \pm 0.50^{\circ} \mathrm{F}\right)$, or less (Efferding 1992b).

- Demonstrating that in-tank hand7ing equipment, including pan and tilt operation, contamination control, and ambient control for the scanner can be designed, fabricated, and operated.

- Confirming that in-tank IR imaging can be accomplished within ALARA, safety, and other Tank Farm operating criteria.

Items that are beyond the scope of this work include the following.

- Optimization of operating parameters. It is clear from the work performed to date that areas such as shielding, equipment, in-tank installation (etc.) would benefit from additional design or development to improve performance and reliability.

- Selection of best equipment and computer programs. There are a number of competitive IR imaging systems, data reduction programs, pan and tilt units (etc.) available on the market. Equipment and software purchased for the present report were carefully chosen. However, the market survey was not exhaustive and the technology has advanced since the time of that survey. 
Rev. 0

- Tank Modeling for Hot Spot Credibility. Modeling of the ferrocyanide tanks continues and is not part of the scope of the IR imaging system tests. This modeling is to determine if a hot spot is a credible event. Results of this analysis are scheduled to be complete in fiscal year (FY) 1993.

\subsection{BACKGROUND}

In the 1950s Hanford Site waste tanks received ferrocyanide-bearing sludges resulting from waste concentration efforts. Radioactive wastes in a slurry form were pumped into their present storage locations in 24 single-shell waste storage tanks, and the solids were allowed to settle. Later other waste forms were added, such as aluminum decladding wastes, evaporator bottoms waste, waste from the cesium ion exchange system in the B Plant, and waste from the strontium semi-works. An In-Tank Solidification (ITS) process also utilized several ferrocyanide tanks, and consequently those tanks contain concentrate and supernate from the ITS process. In Table 1-1 the ferrocyanide tank waste levels are 1 isted as reported in WHC-EP-0182-46 (Hanlon 1992).

Table 1-1. Ferrocyanide Tanks.

\begin{tabular}{|l|c|c|c|c|c|}
\hline \multirow{2}{*}{ Tank } & \multicolumn{2}{|c|}{ Waste depth } & \multirow{2}{*}{ Tank } & \multicolumn{2}{c|}{ Waste depth } \\
\cline { 6 - 6 } & Meters & Inches & & Meters & Inches \\
\hline $241-$ TY-104 & 0.61 & 24 & $241-B Y-108$ & 2.29 & 90 \\
\hline $241-B X-106$ & 0.61 & 24 & $241-B X-111$ & 2.31 & 91 \\
\hline $241-C-111$ & 0.71 & 28 & $241-B Y-107$ & 2.64 & 104 \\
\hline $241-C-109$ & 0.79 & 31 & $241-B Y-112$ & 2.87 & 113 \\
\hline $241-C-108$ & 0.79 & 31 & $241-$ TX-118 & 3.40 & 134 \\
\hline $241-B X-102$ & 1.07 & 42 & $241-B Y-101$ & 3.76 & 148 \\
\hline $241-C-112$ & 1.14 & 45 & $241-B Y-110$ & 3.86 & 152 \\
\hline $241-$ TY-101 & 1.27 & 50 & $241-B Y-103$ & 3.89 & 153 \\
\hline $241-$ T-101 & 1.42 & 56 & $241-B Y-104$ & 3.94 & 155 \\
\hline $241-$ TY-103 & 1.68 & 66 & $241-B Y-111$ & 4.42 & 174 \\
\hline $241-$ T-107 & 1.85 & 73 & $241-B Y-105$ & 4.83 & 190 \\
\hline $241-$ BX-110 & 2.03 & 80 & $241-B Y-106$ & 6.12 & 241 \\
\hline
\end{tabular}

Note: Original data were collected in the English system of units. However, they were converted to SI System [metric system] of units for this report. Conversion back to the English System may introduce round-off error. 
WHC-SD-WM-TRP-218

Rev. 0

It has been postulated that some of the radionuclides could have preferentially settled in such a way as to create local concentrations of heat-generating material (e.g., cesium or strontium). Should concentrations be sufficiently high, the heat generated by radioactive decay could create a therma 1 hot spot. If hot spot temperatures are greater than about $220{ }^{\circ} \mathrm{C}$ $\left(428{ }^{\circ} \mathrm{F}\right.$ ), a potentially dangerous condition could be initiated (Burger and Scheele 1991). At such temperatures, it is postulated that chemical reactions could propagate within the sludge and generate sufficient heat to cause an increase in the heat generation rate beyond the ability of the tank waste to conduct it away. This could lead to thermal runaway.

\subsection{SURFACE TEMPERATURE PATTERNS}

Computer analysis (McLaren 1991) shows that a hot spot within a waste volume where temperatures are high enough to be of concern would create a noticeable temperature pattern on the surface of the waste. This analysis provided patterns against which IR scans could be compared to determine if hot spots were present. It also showed that the depth of the hot spot within the waste has a marked effect on the temperature profiles that are seen on the surface.

\subsubsection{Computer Analysis of Patterns}

Computer analysis (McLaren 1991) of one ferrocyanide tank (241-BY-104) has been conducted to determine if the heat load and thermal characteristics of the waste could be determined by thermal analysis. Three-dimensional models were created and evaluated using specialized computer codes. Analyses indicate that, in a $1-m$ cube, the concentration of radionuclides would have to be 150 times greater than the tank-average concentration before a hot spot would be of concern.

The results of the computer analyses modeled on 241-BY-104 for such a hot spot of $500 \mathrm{BTU} / \mathrm{hr}$ in a 1 meter (3.3 feet) cube placed 22.9 centimeters (9 inches) below the waste surface are shown in Figure 1-1. As shown in Figure 1-1, the modeled hot spot produces a pronounced temperature peak on the waste surface. The temperature difference between the center of the peak and the surrounding surface is about $4{ }^{\circ} \mathrm{C}\left(7.2^{\circ} \mathrm{F}\right)$. The first three $1{ }^{\circ} \mathrm{C}$ contours away from the peak are spaced about 1 meter $\left(3.3\right.$ feet) apart (i.e., $1{ }^{\circ} \mathrm{C} / \mathrm{m}$ or $0.6^{\circ} \mathrm{F} / \mathrm{ft}$ ). When the same hot spot is placed on the bottom of the tank, the temperature peak is about $3{ }^{\circ} \mathrm{C}\left(5.4^{\circ} \mathrm{F}\right)$ above the surrounding surface, as shown in Figure 1-2. Here the contours are much more spread out, dropping about $0.3^{\circ} \mathrm{C} / \mathrm{m}\left(0.2^{\circ} \mathrm{F} / \mathrm{ft}\right)$. As shown in Figures $1-1$ and $1-2$, the temperature peak is recognizable in both cases. But, with the hot spot near the surface, the temperature peak is much more prominent, as the temperature contours are more closely spaced.

Distinguishing between a deep, high temperature hot spot and one of lower temperature nearer to the surface is not practical or necessary. The worst case is a high-temperature, deep hot spot, and that would be the subject of the analysis of the surface temperature data. The presence of an overlying saltcake layer reduces the surface temperature variation,.because the saltcake 
Figure 1-1. Computer Analysis Modeled on 241-BY-104 for a Hot Spot Nine Inches Below the Surface.

Calculated 500 BTU/hr Hot Spot at Top of Tank ( $1^{\circ} \mathrm{C}$ contours)
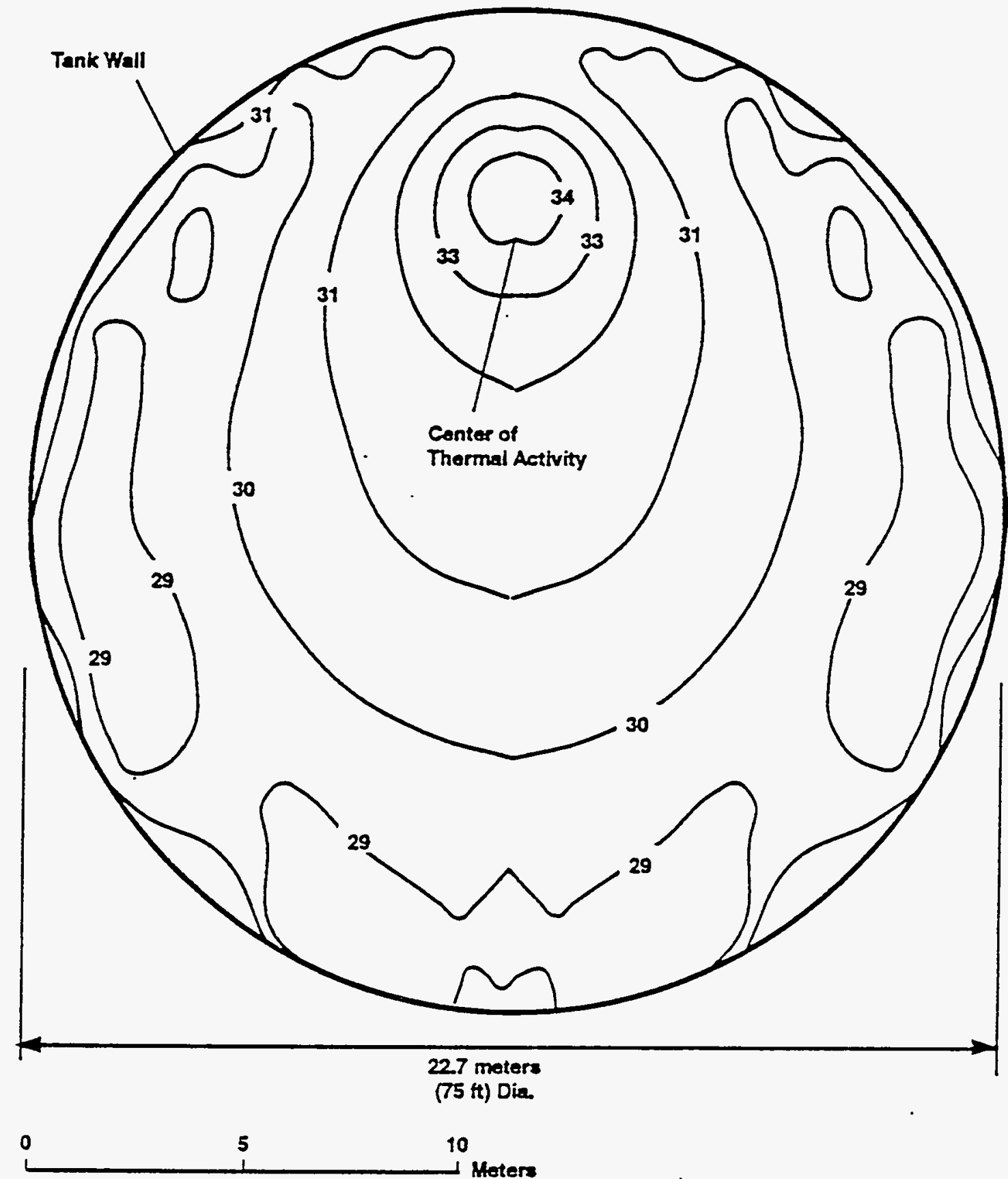
- WHC-SD-WM-TRP-218

Rev. 0

Figure 1-2. Computer Analys is Modeled on 241-BY-104 for a Hot Spot on the Tank Bottom.

Calculated 500 BTU/hr Hot Spot at Bottom of Tank ( $1^{\circ} \mathrm{C}$ contours)
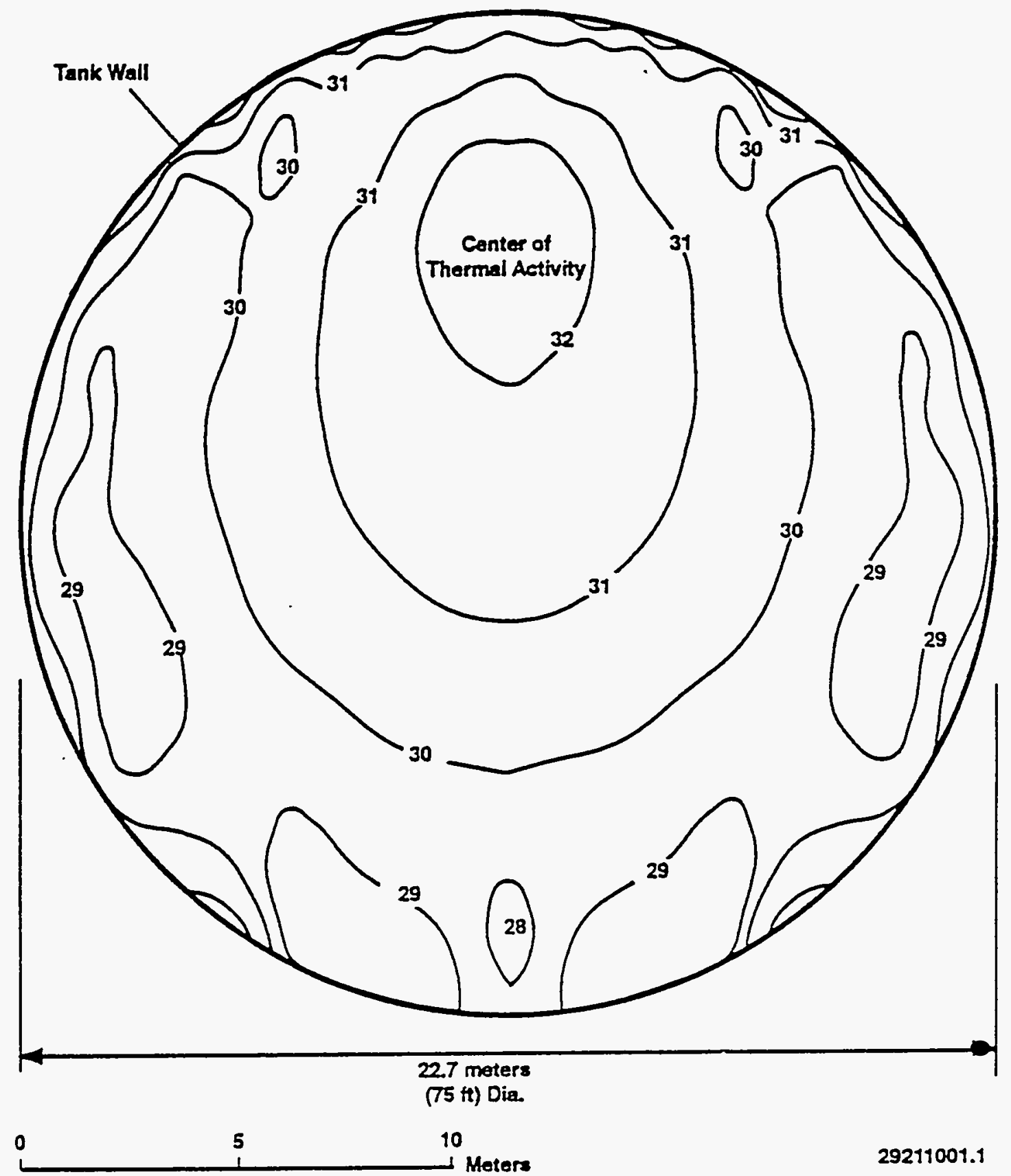

29211001.1 
WHC-SD-WM-TRP-218

Rev. 0

has a lower thermal conductivity than the sludge beneath it. Thicker saltcake layers reduce the temperature variations more than thinner ones. As a result, there will be a depth of saltcake that would mask the presence of a hot spot whose temperatures could be high enough to be of concern. Whether a layer of such thickness exists depends on the individual tank. Consequently, a hot spot whose temperatures are high enough to be of concern may not be detectable by surface temperature measurements if there is a thick enough layer of saltcake over it.

\subsubsection{Limits of Hot Spot Detectability Based on Modeling}

The limits of hot spot detectability are not precisely known, and will vary depending on the contents of each tank. However, based on the computer modeling performed to date (see Section 1.3.1) it appears that tank wastes as deep as those in tank 241-BY-104 could be assayed with IR imaging if the saltcake layer is not too thick. Table 1-2 shows that there are eight ferrocyanide tanks in which the waste is approximately equal to, or deeper than, the 241-BY-104 waste.

Table 1-2. Deepest Ferrocyanide Tanks.

\begin{tabular}{|l|c|c|}
\hline \multirow{2}{*}{ Tank } & \multicolumn{2}{|c|}{ Waste depth } \\
\cline { 2 - 3 } & Meters & Inches \\
\hline $241-$ TX-118 & 3.40 & 134 \\
\hline $241-B Y-101$ & 3.76 & 148 \\
\hline $241-B Y-110$ & 3.86 & 152 \\
\hline $241-B Y-103$ & 3.89 & 153 \\
\hline $241-B Y-104$ & 3.94 & 155 \\
\hline $241-B Y-111$ & 4.42 & 174 \\
\hline $241-B Y-105$ & 4.83 & 190 \\
\hline $241-B Y-106$ & 6.12 & 241 \\
\hline
\end{tabular}

These eight tanks reflect various degrees of detectability. Some are marginal, such as 241-BY-105, 241-BY-106, 241-BY-111, which are unlikely to be amenable to IR detection of a hot spot using surface temperature mapping because the waste depth is great. However, waste in the other 21 of the 24 ferrocyanide tanks is shallower, which renders the waste more suitable to IR imaging and radiometric techniques. Analyses of ferrocyanide tanks containing significant saltcake will be required to evaluate detectability limits on a tank-by-tank basis. 
WHC-SD-WM-TRP-218

Rev. 0

\subsection{DESCRIPTION OF THE EQUIPMENT}

\subsection{SCANNER}

The infrared imaging system (see Figure 2-1) is an FLIR Systems, Inc. (FSI), Mode 7300 consisting of a scanner assembiy, image processor, and color display. An additional component of the IR system is the Thermal Image Management System (TIMS) connected to a 386 personal computer. Also, there is a video home system (VHS) tape player and a black and white display.

The following vendor specifications for radiometric measurement on the IR imaging system came from the factory. The vendor specifications are as follows:

- Temperature range (of surface to be scanned)

- Temperature accuracy

$$
\begin{aligned}
& \text { Room temp to } 1,500{ }^{\circ} \mathrm{C}\left(2,732{ }^{\circ} \mathrm{F}\right) \\
& -\quad \pm 4.0^{\circ} \mathrm{C}\left( \pm 7.2{ }^{\circ} \mathrm{F}\right) \text { or } \pm 4 \% \text { of } \\
& \text { reading (whichever is greater) }
\end{aligned}
$$

Subsequent testing (see Sections 3.0 and 4.0 ) determined the values specific to application in the Hanford Site waste tanks.

\subsection{OPERATION OF THE SCANNER}

The IR scanner utilizes a linear, multi-detector array that scans using a rotating eight-sided mirror. There are 30 detector elements in the array. As each mirror face rotates across the field of view, each element is exposed to a line of the field. Subsequent mirror faces expose each element to subsequent 7 ines. Consequently, there are a total of 240 scan lines per frame.

One frame is scanned with each revolution of the mirror. The system normal1y operates at 30 frames per second. The scanner can be operated in a averaging mode to improve image quality.

Detectors are cooled to $-73{ }^{\circ} \mathrm{C}\left(-100^{\circ} \mathrm{F}\right)$ with a Peltier cooler. Each detector has its own multi-stage amplifier. The multistage amplifiers are of hybrid complementary metal oxide semiconductor (HCMOS) construction, and are sensitive to ionizing radiation. Their total dose life is estimated to be on the order of 1,000 R (Messenger and Ash 1986). The entire scanner mechanism is cooled by a fan which provides roughiy $1.5 \mathrm{ft}^{3} / \mathrm{min}(0.7 \mathrm{~L} / \mathrm{sec})$ air flow across the back of the cooler detector assembly. The scanner was purchased with two standard lenses and one wide-angle lens. * The lenses were calibrated with the system at the factory; the calibration data files for each are stored in the image processor. The image processor and scanner are connected with a cable calibrated especially for the system. Exchanging any of the units with uncalibrated equipment will yield inaccurate results.

\footnotetext{
*Both the standard lenses were used.
} 
Figure 2-1. Infrared Scanner System.

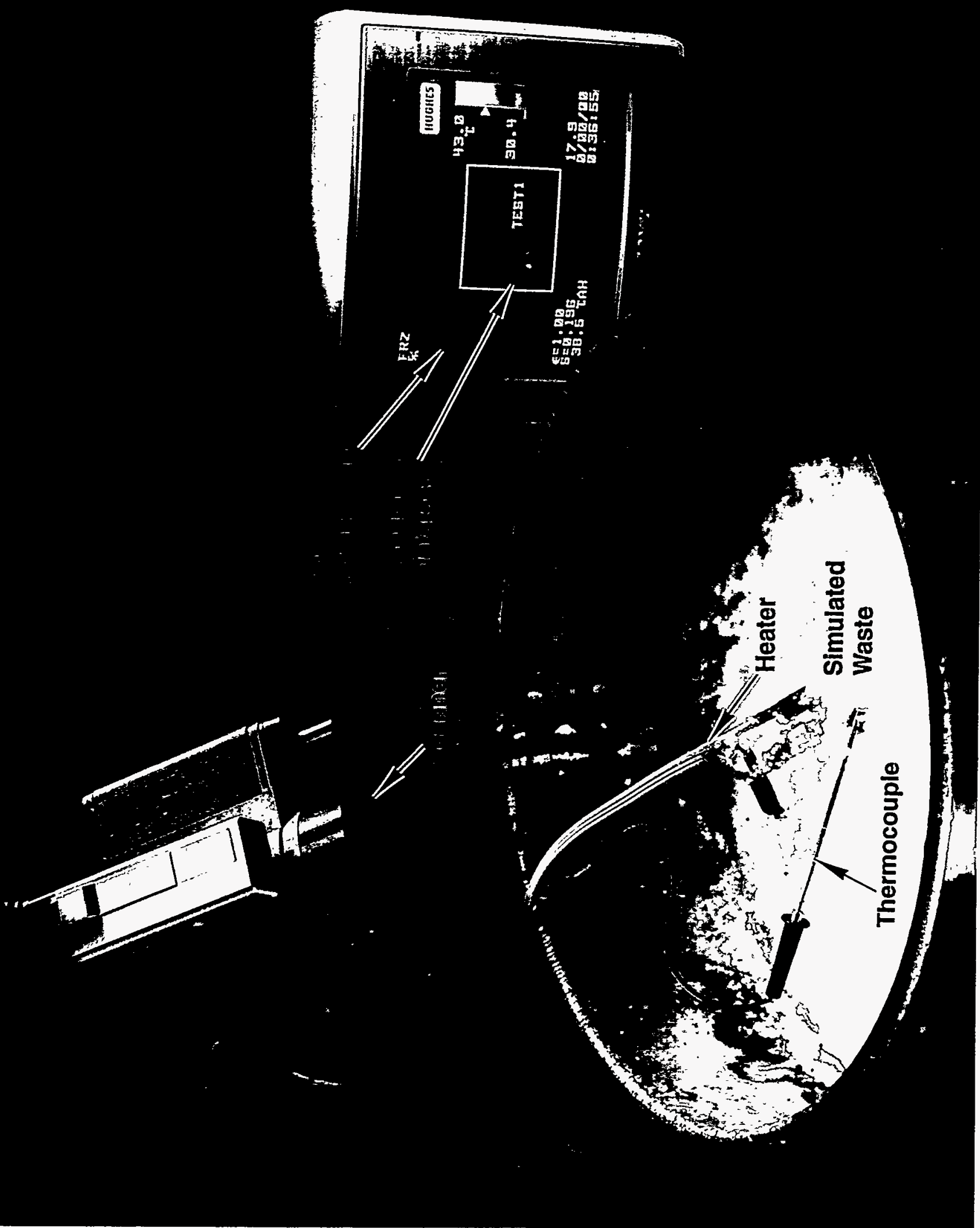

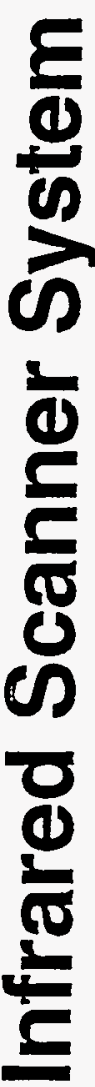


WHC-SD-WM-TRP-218

Rev. 0

\subsection{OPERATION OF THE IMAGE PROCESSOR}

The processor receives the analog signal from the scanner and modifies it for imaging and radiometric measurements. The main functions are as follows:

- Focus

- Range setting

- Level of temperature.

The processor has outputs to a color display and to the black and white video recorder. Recorded information is kept in a black and white video format for use with the TIMS. The TIMS is a post-operation data analysis system that allows the user to evaluate the information in greater detail on a desktop computer. A variety of histograms, variable emissivity settings, transmission loss settings, digital image storage, and printout features are available.

\subsection{THERMAL IMAGE MANAGEMENT SYSTEM}

The TIMS processes data from the videotaped input of a frame grabber and processor board. The TIMS transforms the levels of intensity in a black and white video signal to the radiometric values of the infrared image.

Consequentiy, data must be recorded in black and white with the number of intensity levels, the highest temperature, and the lowest temperature to properly reconstruct the thermal image. The IR imaging system has a recording mode that allows for automatic parameter setting. This mode was used for the operation of the IR imaging system in the tank environment.

Software options allow the user to examine data collected after the scan. Although the data is analyzed by the computer in black and white, the user has the option of viewing in color. Frames of interest can be saved in a digital format for future use and transformed to color by computer enhancement (see Figure 2-2). Data can be presented in histogram formats, using line profiles or areas of interest, with temperature point values displayed. Areas of interest also display minimum, maximum, and mean values. Display options include isotherms, zoom, averaging, emissivity settings, transmission setting, and global parameters settings (color bar, high/low temperature, palette, etc.).

\subsection{INFRARED SCANNER HOUSING ASSEMBLY}

Figures 2-3 and 2-4 show the IR scanner housing assembly and associated systems (see also drawing $\mathrm{H}-2-81787$, in Figure 2-5). Lead shielding houses the IR scanner in order to protect the detectors and integrated circuits from radiation damage. Because the housing changes the normal ability of the IR imaging system to cool itself, and because contamination should not enter the housing, a purge gas system was designed for the IR imaging system. The purge gas flow rate for this enclosure is set to control the scanner temperature to vendor specifications (see Section 3.5). 
Figure 2-2. Color-Enhanced Scan Data (Example).

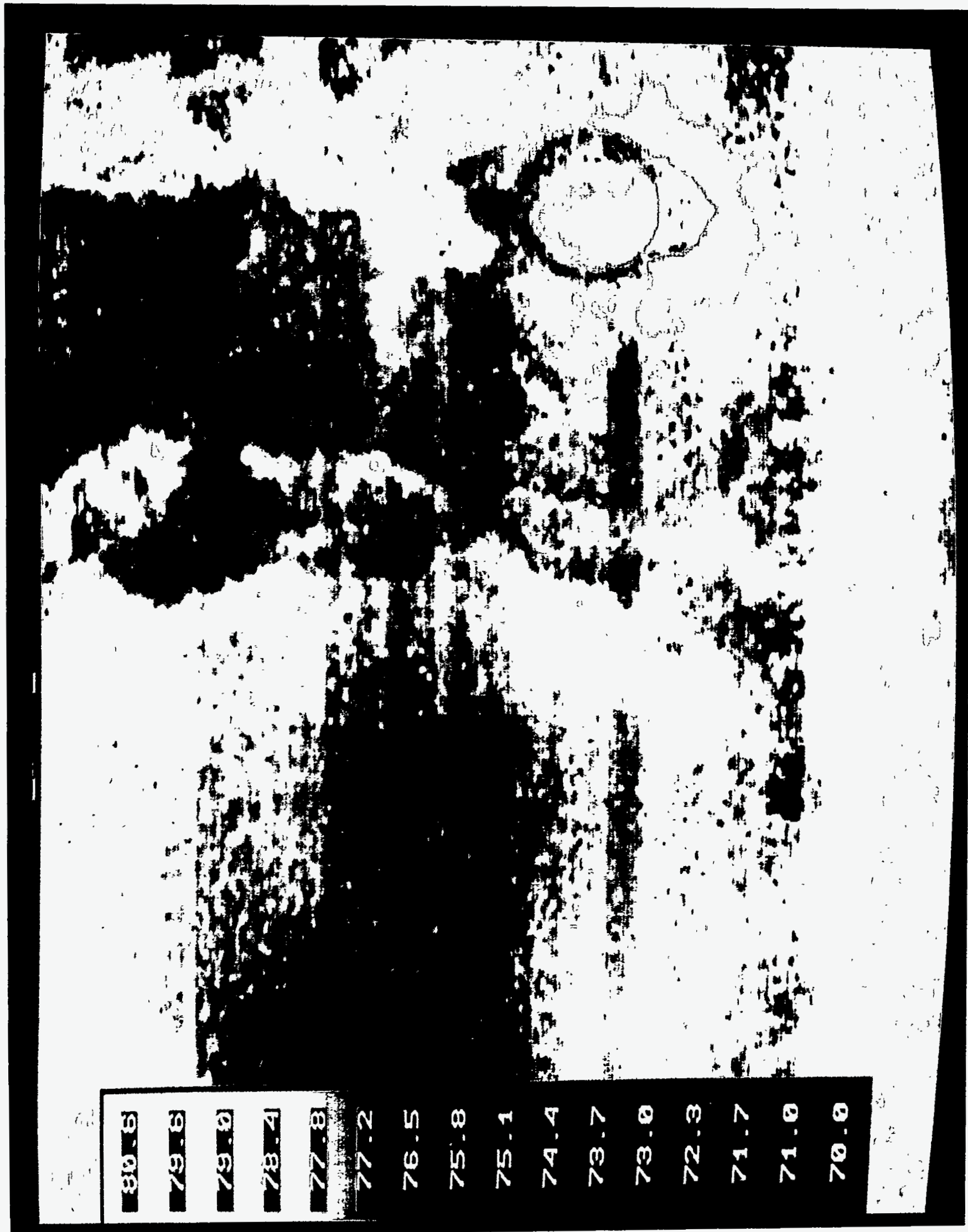


WHC-SD-WM-TRP-218

Rev. 0

Figure 2-3. Infrared Scanner Installation.

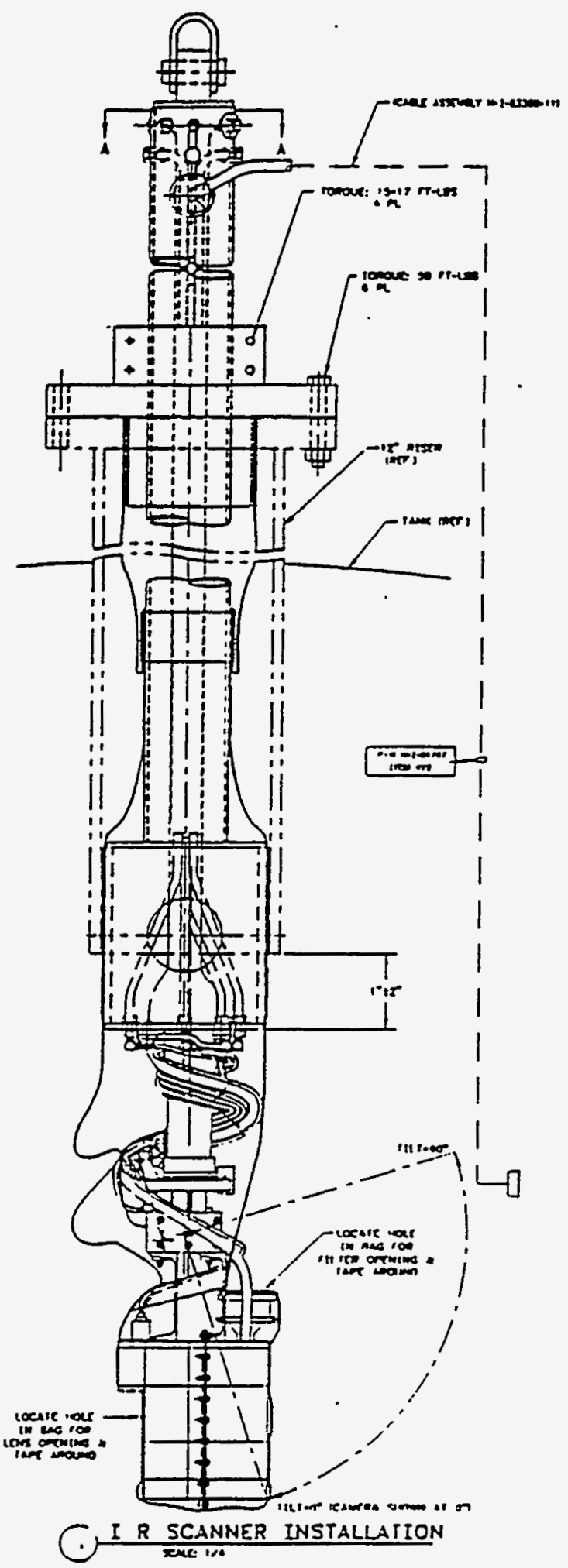


WHC-SD-WM-TRP-218

Rev. 0

Figure 2-4. Infrared Scanner Control Schematic.

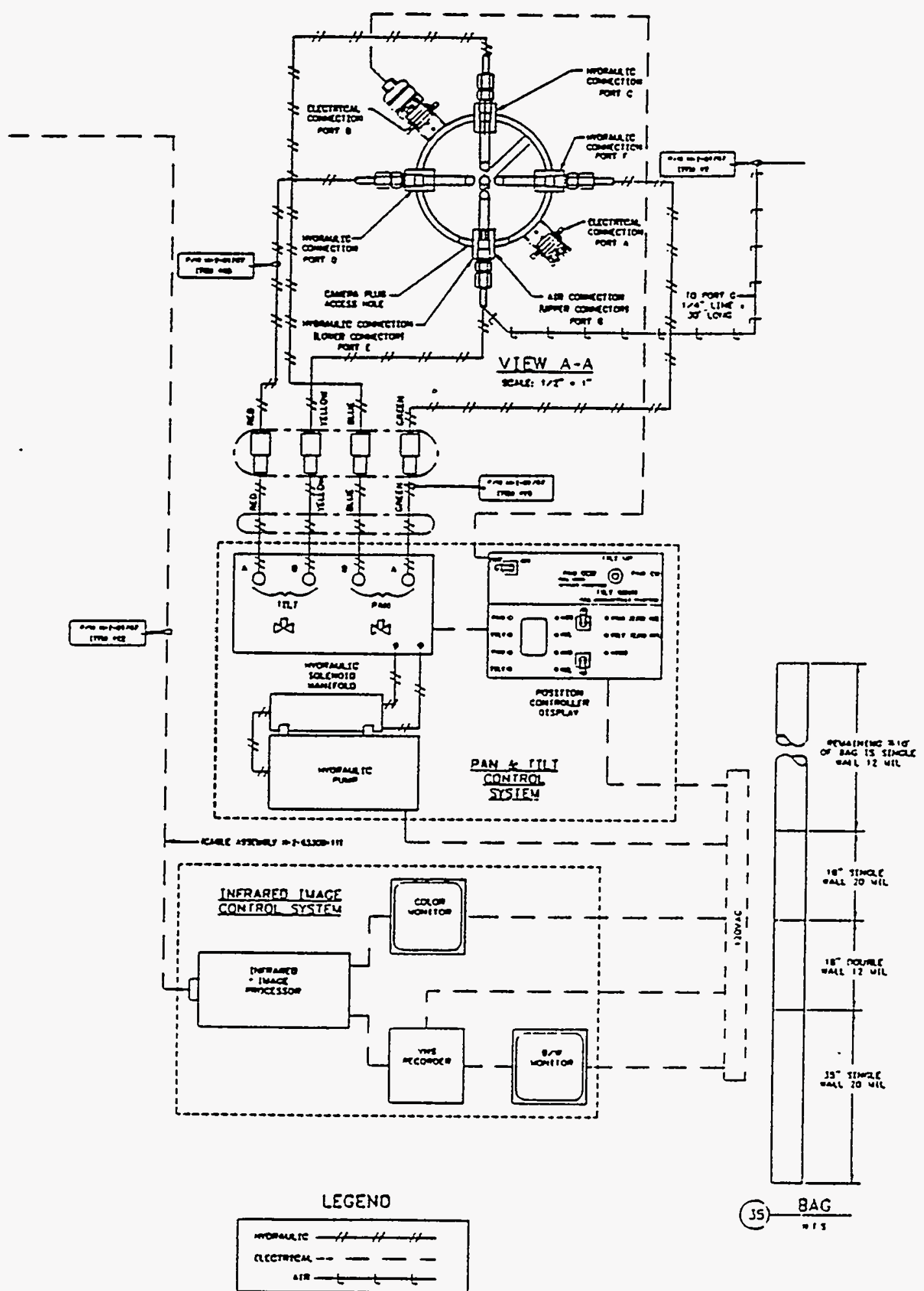




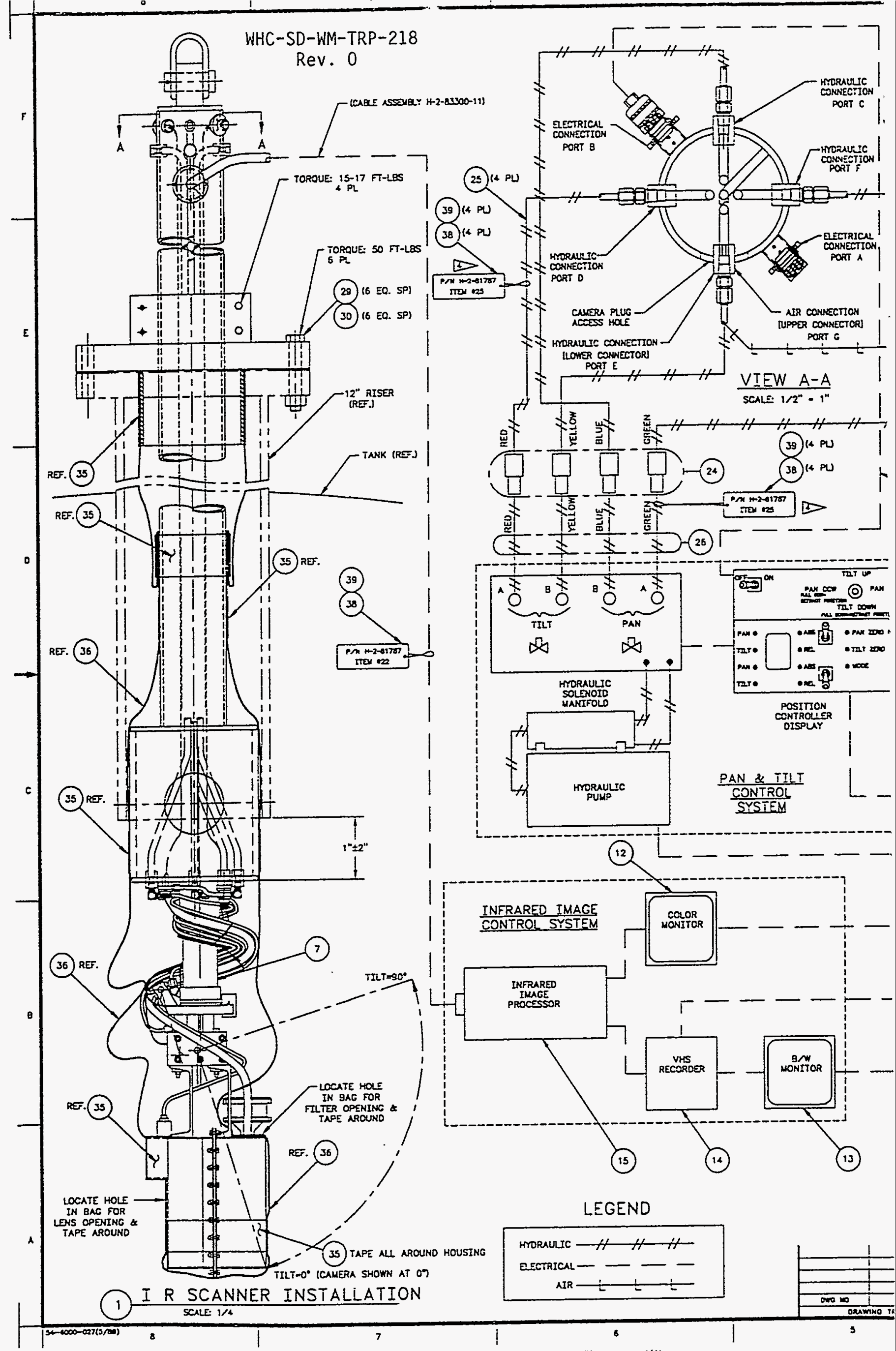



The pan and tilt unit attaches the IR scanner to the stem, rotates the scanner $358^{\circ}$, and tilts it $90^{\circ}$ from vertical to horizontal. The $4.85-\mathrm{m}$ $(16-f t)$ stem houses the hydraulic, gas, and electrical cables. The last 1 to $1.5 \mathrm{~m}(3$ to $5 . \mathrm{ft})$ of these cables extend out of the stem and wind and unwind around the pan and tilt unit when it positions the IR scanner. The assembiy is supported on a $0.30 \mathrm{~m}$ (12-in.) flange by a split clamp welded to a $0.30-\mathrm{m}$ (12-in.) flange plate. The depth of the riser in the tank can be matched to that of the IR scanner by adjusting the flange and clamp. Overall length of the assembly is approximately $5.8 \mathrm{~m}(19 \mathrm{ft})$; the approximate weight is $386 \mathrm{~kg}$ $(850 \mathrm{~Tb})$.

Additional equipment to run the IR scanner includes the hydraulic pump for the pan and tilt unit, the control for the pan and tilt, the nitrogen gas purge supply, and the computer control and video recording equipment for the IR imager. A plastic sleeve encased the entire assembly from the flange connection down to the IR scanner. The lens and the purge gas filter were open to the atmosphere. 
WHC-SD-WM-TRP-218

Rev. 0

This page intentionally left blank.

$2-10$ 
WHC-SD-WM-TRP-218

Rev. 0

\subsection{LABORATORY TESTS OF INFRARED IMAGING SYSTEM}

The radiometric measurement of the IR source is a function deriving from the target temperature, atmospheric attenuation, target material emissivity, angle of incidence, and background radiation. These factors affect the data quality gathered from the IR imaging system. The effects of these factors are described below.

Objectives of IR Taboratory tests were to (1) determine the sensitivity of the IR imaging system to waste material temperatures; and (2) define the effects of atmospheric attenuation, waste surface emissivity, angle of incidence, ambient temperature variations, and gamma radiation fields as they may appear in ferrocyanide waste tanks. In addition, general mechanical functions were tested (see Section 3.7). The data in Sections 3.1 through 3.5 are discussed more fully in WHC-SD-WM-TRP-067 (Mailhot and Rankin 1992). The data in Sections 3.6 and 3.7 are more fully discussed in WHC-SD-WM-ER-154 (Efferding 1992a), and WHC-SD-WM-ATR-027 (Griffin 1992), respectively.

Of the IR imaging system specifications, temperature sensitivity is the most useful. The temperature sensitivity indicates temperature differences between areas in an infrared image. Locating hot spots is the goal in using this technology. Analyses (see Section 1.3.1) show that temperature differences between areas will indicate a hot spot below the surface. While the temperature being detected can be inaccurate by as much as $\pm 4{ }^{\circ} \mathrm{C}$ $\left[\left( \pm 7.2^{\circ} \mathrm{F}\right)\right.$, the accuracy given by the vendor], it will be inaccurate uniformly for the entire tank. This is because factors such as humidity, background radiation, and emissivity affect the IR imaging system accuracy equally in each image. Other factors, such as incident angle, have only a gradual effect from frame to frame. That is to say, the reading may be off, for example, by 2 degrees, but it will be off 2 degrees everywhere in the tank. However, if temperature sensitivity were off by that much, the IR imaging system would be of no use. This is why temperature sensitivity, with a more rigorous specification, is so useful. Most of the testing was geared to determine this sensitivity. Both the sensitivity under ideal conditions (Section 3.1) and the sensitivity under in-tank conditions (Section 3.6) were determined. This testing is described in the following sections.

\subsection{CALIBRATION BY BLACK BODY STANDARD}

\subsubsection{Description of Black Body Calibration}

This testing was used to determine the accuracy and sensitivity of the IR imaging system under ideal conditions. It provides a baseline for data anatysis.

A black body is an ideal source of radiation (usually associated with IR radiation) for which the wavelength distribution is dependent only on its temperature in accordance with Planck's radiation law. The fraction of IR energy that a non-black body would radiate, in comparison to a black body, is called its emissivity. Infrared imaging devices determine temperature by 
WHC-SD-WM-TRP-218

Rev. 0

measuring IR radiation emitted from an object. The temperature reading

obtained from a non-black body is lower than that from a black body. To test the accuracy of the IR imaging system, radiometric measurements were taken of a commercial black body source. By definition, an ideal black body has an emissivity of 1 . Since this is only true in theory, the black body source for this test had an emissivity of 0.99 .

\subsubsection{Summary of Black Body Calibration}

The IR imaging system read temperatures of the black body source set at typical in-tank surface temperatures -- 20 to $54.4{ }^{\circ} \mathrm{C}$ (68 to $130{ }^{\circ} \mathrm{F}$ ) (see Hanlon 1992; Mailhot and Rankin 1992). To control variables of the test, the measurements were performed by using the known emissivity and temperatures of the black body calibration source. The IR imaging system was aligned perpendicular to the source at a distance of $1 \mathrm{~m}(3.3 \mathrm{ft})$, at which distance transmission losses are negligible.

\subsubsection{Results of Black Body Calibration}

Black body tests have shown that, under ideal conditions, the equipment is capable of measuring actual temperatures to within $\pm 0.50{ }^{\circ} \mathrm{C}\left( \pm 0.90^{\circ} \mathrm{F}\right)$. The tests also have shown that, under ideal conditions, temperature sensitivity $\mathrm{can}$ be determined to within $\pm 0.15^{\circ} \mathrm{C}\left( \pm 0.27{ }^{\circ} \mathrm{F}\right)$.

\subsubsection{Validation of Black Body Calibration}

The calibration was done as impact level 3 according to Westinghouse Hanford Company (WHC) WHC-CM-1-3, Management Requirements and Procedures, MRP-5.43, Revision 5, and WHC-CM-6-1, Standard Engineering Practices, EP-4.2. An accepted industry standard black body was used. Two qualified engineers witnessed and signed the test results. All instrument calibrations (thermocouples, RTDs, etc.) were up-to-date and recorded as required by WHC procedures.

\subsubsection{Conclusions}

The tests have shown that, under ideal conditions, temperature changes across the scanned field of view (temperature sensitivity) can be determined to within $\pm 0.15^{\circ} \mathrm{C}\left( \pm 0.27^{\circ} \mathrm{F}\right)$. Sensitivity performance would not be this high during in-tank operation, however. See Section 3.6 for in-tank sensitivity. The tests also show that, under ideal conditions, the equipment temperature accuracy is within $\pm 0.50{ }^{\circ} \mathrm{C}\left( \pm 0.90^{\circ} \mathrm{F}\right)$. This is greater accuracy than the manufacturer specifies, due to the small temperature range. The manufacturer specified an accuracy to encompass the entire temperature range of the scanner. 
Rev. 0

\subsection{EMISSIVITY}

\subsubsection{Description of Emissivity Test}

This test was performed to determine the emissivity range of the expected surface of the ferrocyanide waste. Emissivity is a variable input into the IR image processor to aid in analysis of radiometric readings. For most materials, emissivity varies with wavelength, chemical composition, temperature, surface roughness, and angle of incidence. Three simulants were developed and tested for this test: one by Pacific Northwest Laboratory (PNL), and two by the WHC Chemical Engineering Laboratory. The emissivities were determined by comparison to the same surface with a known emissivity.

\subsubsection{Summary of Emissivity Test}

The simulant was tested for emissivity at $1.0 \mathrm{~m}$ (39 in.) and $0.5 \mathrm{~m}$ (20 in.). Greater distances similar to the tank conditions were tested; see Section 3.6. A waste tank simulant was prepared and analyzed by PNL based on the process chemicals and end products of the uranium recovery process (Peters et al 1991). In addition, two more simulants were made up by WHC based on a 1976 core sample taken of the 241-BY-104 waste tank and on samples taken from evaporator bottoms (Mailhot and Rankin 1992). Emissivities of the simulants were studied at different angles of incidence. Emissivity was determined by comparing the IR imaging system temperature reading with the value measured by a RTD. Emissivity was also determined by comparing the IR imaging system temperature reading of an emissivity coating rated at 0.95 and the temperature reading of an adjacent simulant surface.

\subsubsection{Results of Emissivity Test}

Results of both studies were in agreement for the emissivity and for the angle of incidence. The emissivity range is 0.94-0.95. Varying the angle of incidence demonstrated that the scanner could view the waste tank surface up to a $60^{\circ}$ angle of incidence without reducing the IR intensity detected from the surface (see Figure 3-1). The roughness of the simulant surface seems to promote uniform emission over a large range of incident angles.

\subsubsection{Validation of Emissivity Test}

The emissivity measurement was done as impact level 3 (WHC 1988 and WHC 1991). Two separate laboratories performed emissivity tests on the imaging system. The PNL tests were witnessed and verified by WHC. ATI calibrations for the instruments against which IR temperature was compared (thermocouples, RTDs, etc.) were up-to-date and recorded. An accepted emissivity standard black paint was used as a cross-check after the emissivity was determined by temperature comparison. At least two qualified engineers witnessed and signed the WHC test results. 
WHC-SD-WM-TRP-218

Rev. 0

Figure 3-1. Emissivity at Varying Angles of Incidence.

Effect of Angle of Incidence

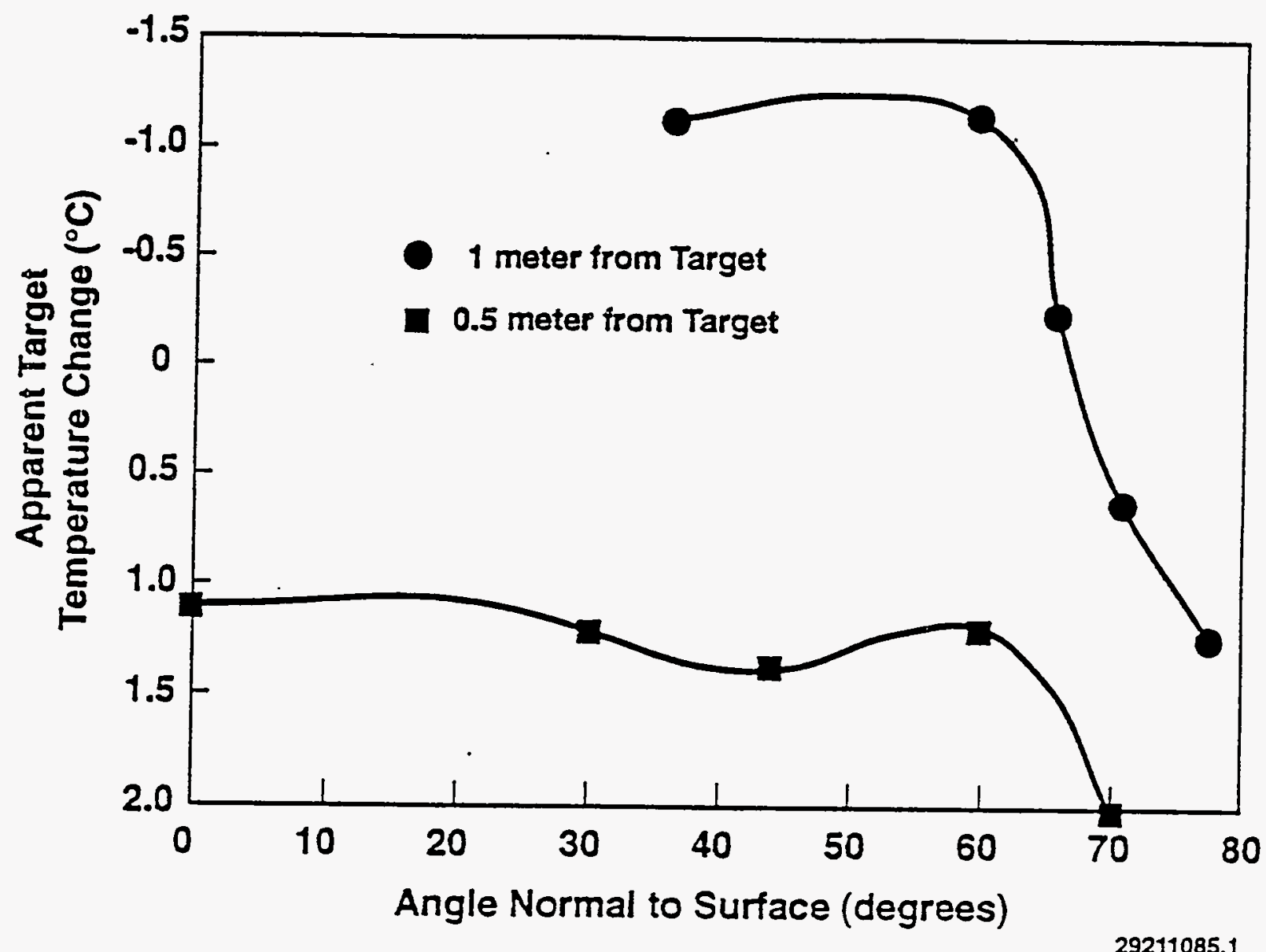


WHC-SD-WM-TRP-218

Rev. 0

\subsubsection{Conclusions}

The test performed by WHC indicated that the emissivity of the simulant was 0.95, which is very close to the 0.94 emissivity PNL had determined. An angle of incidence up to $60^{\circ}$ does not significantly affect the temperature measurement. More research is required to determine if a 71 the ferrocyanide tanks can be viewed at or above this angle.

\subsection{ATMOSPHERIC ATTENUATION}

\subsubsection{Description of Atmospheric Attenuation Test}

Transmission losses are caused by atmospheric attenuation resulting from the different absorption bands present over the operating range of the IR imaging system (wavelengths of 3.2 to 5.6 micrometers). Most of these absorption bands are created by water vapor and carbon dioxide. The radiation in the carbon dioxide band (wavelengths of 4.2 to 4.4 micrometers) is almost completely absorbed for viewing distances over $3 \mathrm{~m}(10 \mathrm{ft})$. Attenuation caused by the different humidities will vary depending on viewing distance.

Ferrocyanide tanks have moderate waste surface temperatures and ambient dome space temperatures. The maximum expected waste temperature to be encountered is $54.4^{\circ} \mathrm{C}$. (130 $\left.{ }^{\circ} \mathrm{F}\right)$, with the usual surface temperature averaging around $27{ }^{\circ} \mathrm{C}\left(81^{\circ} \mathrm{F}\right)$. Dome space temperature (as measured by the top thermocouple of the thermocouple tree) varies between $18{ }^{\circ} \mathrm{C}$ and $27^{\circ} \mathrm{C}\left(64{ }^{\circ} \mathrm{F}\right.$ and $81^{\circ} \mathrm{F}$ ) in ferrocyanide tanks.

\subsubsection{Summary of Atmospheric Attenuation Test}

To predict temperature loss for in-tank IR imaging, the computer code LOWTRAN 7 was used (see Air Force Geophysics 1990; Mailhot and Rankin 1992). The program calculates temperature loss for different atmospheres defined by the following parameters: humidity, distance, source temperature, environmental temperature, background radiation, and wavelength. Atmospheric attenuation was measured in the laboratory using the IR imaging system and a black-body calibration source. Different attenuations were obtained by varying the distance between the scanner and the source in the available humidities found in the laboratory, which varied between $30 \%$ and $60 \% \mathrm{RH}$.

\subsubsection{Results of Atmospheric Attenuation Test}

The practical maximum distance for viewing in the tank dome space is $14 \mathrm{~m}$ $(46 \mathrm{ft})$. As can be seen in Figure $3-2$, the atmospheric attenuation is calculated to be less than $2.2^{\circ} \mathrm{C}\left(4.0^{\circ} \mathrm{F}\right)$ in a typical ferrocyanide waste tank. There is a potential limitation if higher humidity is present in the waste tanks. 
Figure 3-2. Temperature Loss Calculated in Ferrocyanide Tanks.

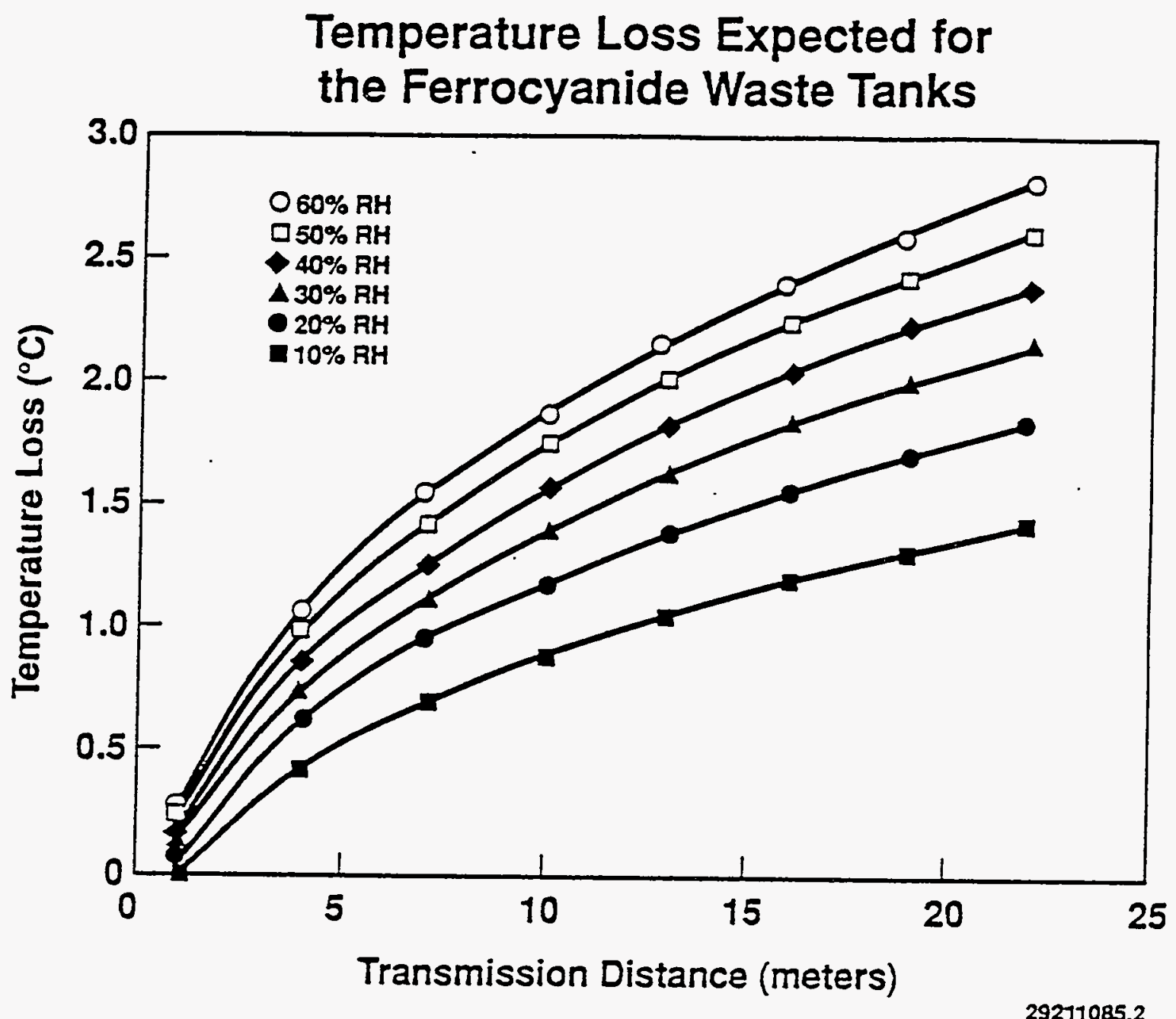


WHC-SD-WM-TRP-218

Rev. 0

\subsubsection{Validation of Atmospheric Attenuation Test}

The atmospheric attenuation test was done as impact level 3 (WHC 1988 and WHC 1991). An accepted industry standard black body was used. Two qualified engineers witnessed and signed the test results. All instrument calibrations (thermocouples, RTDs, psychrometers, etc.) were up-to-date and recorded as required by WHC procedures.

\subsubsection{Conclusions}

The thermal loss associated with atmospheric attenuation is negligible for hot spot detection. Although the scanner was tested to $60 \% \mathrm{RH}$, further work is needed to quantify the effect of relative humidity higher than $50 \%$. The practical maximum distance for viewing in the tank dome space is $14 \mathrm{~m}$ $(46 \mathrm{ft})$. Some tanks may have risers available to one side of the tank and not the other, although the number of these tanks has not been tabulated. Such tanks as these have distances greater than $14 \mathrm{~m}(46 \mathrm{ft})$ for a portion of the IR scans. It should be noted that there is an increase in temperature loss with increasing distance. While this effect is negligible, testing has determined that hot spots can be identified equidistant from the scanner providing a redundant check. This is done in addition to analyzing the results at radial distances from the scanner; circumferential analysis on equidistant radij identify any patterns characteristic of a hot spot (Efferding 1992b).

\subsection{GAMMA RADIATION EFFECTS}

\subsubsection{Description of Gamma Radiation Effects Test}

The maximum expected gamma radiation dose rate in the ferrocyanide tanks for the IR imaging system components (as shown in Figure 2-3) is approximately $20 \mathrm{R} / \mathrm{hr}$ (Morford 1991). This radiation is not infrared, but has more than sufficient energy per photon to move electrons across the energy band gap of the IR detector. This effect could change the response of more radiation-sensitive components, such as integrated circuits or detector arrays. Subjecting the scanner to gamma radiation while monitoring a surface of known temperature could cause unwanted short-term effects of radiation on the scanner (i.e., the accuracy of the sensitivity could be affected).

\subsubsection{Summary of Gamma Radiation Effects Test}

To test for this potential effect, the IR scanner was mounted to read the temperature of an aluminum plate while in the presence of a ${ }^{37} \mathrm{Cs}$ source. $10 \mathrm{Ci}$ and $100 \mathrm{C} i$ sources were used (Mailhot and Rankin 1992).

\subsubsection{Results of Gamma Radiation Effects Test}

The scanner was able to register a $0.2{ }^{\circ} \mathrm{C}\left(26.8\right.$ to $\left.27.0{ }^{\circ} \mathrm{C}\right)\left[0.4{ }^{\circ} \mathrm{F}(80.2\right.$ to $\left.80.6^{\circ} \mathrm{F}\right)$ ] temperature gradient across the plate. Additionally, the scanner could detect a $1.3{ }^{\circ} \mathrm{C}\left(2.3^{\circ} \mathrm{F}\right)$ change in plate temperature when the room air conditioner came on. However, none of these readings were affected by the 
WHC-SD-WM-TRP-218

Rev. 0

presence/absence of the gamma radiation field. The total time that the scanner spent in the radiation was less than 5 minutes.

\subsubsection{Validation of Gamma Radiation Effects Test}

The radiation effects test was done as impact level 3 (WHC 1988 and WHC 1991). Accepted industry standard gamma sources were used. Two qualified engineers witnessed and signed the test results. All instrument calibrations (thermocouples, RTDs, etc.) were up-to-date and recorded.

\subsubsection{Conclusions}

No short-term effects were measured on the radiometric readings during operation in a gamma field. Effects of long-term doses were estimated using data gathered from documentation of the components of the scanner. The expected 1 ife of this equipment is 1,000 R total integrated dose (Messenger and Ash 1986). The equipment may require maintenance (recalibration) as this total dose is approached. Further testing (e.g., destructive tests) will be necessary to determine the dose capacity.

\subsection{AMBIENT TEMPERATURE}

\subsubsection{Description of Ambient Temperature Test}

The scanner requires enclosure in a purged, shielded container when it is used in a waste tank. The lens is the only part of the scanner body exposed to the tank atmosphere. The effects of operating the scanner in an environment different than the one it is viewing were studied. The imaging processor compensates for background IR radiation by measuring the temperature of the scanner and matching it to an internal reference surface temperature. This internal reference surface temperature must be controlled to approximately the same as that of the transmission path (ambient). The vendor requires this internal temperature to be within $+4.0^{\circ} \mathrm{C}\left(+7.2^{\circ} \mathrm{F}\right)$ of the ambient temperature.

\subsubsection{Summary of Ambient Temperature Test}

The IR scanner was operated in an environmental chamber to measure how its local environmental temperature influenced the reading it produced. The local environment temperature was controlled using a purge gas (nitrogen) in the chamber. The internal temperature response of the scanner to a varying cooling rate was measured.

\subsubsection{Results of Ambient Temperature Test}

The nitrogen purge rate found to keep the scanner in the enclosure within the $+4.0^{\circ} \mathrm{C}\left(+7.2^{\circ} \mathrm{F}\right)$ range was $0.7 \pm 0.1 \mathrm{~L} / \mathrm{sec}\left(1.5 \pm 0.2 \mathrm{ft}^{3} / \mathrm{min}\right)$ during 
WHC-SD-WM-TRP-218

Rev. 0

laboratory tests. The time to attain ambient temperature is important in order to minimize the radiation exposure during installation. 12 to

48 minutes were required for warm-up depending on the difference between the

IR system temperature at startup and ambient temperature.

\subsubsection{Validation of Ambient Temperature Test}

The nitrogen purge rate verification was done as impact level 3 (WHC 1988 and WHC 1991). Two qualified engineers witnessed and signed the test results. A11 instrument calibrations (thermocouples, RTDs, etc.) were up-to-date and recorded.

\subsubsection{Conclusions}

This test demonstrated that the equipment will accurately compensate for the background IR radiation if the internal temperature of the IR scanner does not vary from the ambient temperature of the transmission path by more than the vendor specification. These conditions can be readily met by adjustment of purge gas flow rate.

\subsection{SYSTEM PERFORMANCE UNDER IN-TANK CONDITIONS}

\subsubsection{Description of System Performance Test}

This laboratory test combined several variables to determine the temperature ranges the IR imaging system could detect. The variables were distance, humidity, and angle of incidence. The IR imaging system also viewed various surface shapes (convex regions, concave regions, flat regions, etc.) to determine the effects of surface geometry.

\subsubsection{Summary of System Performance Test}

A laboratory test was set up utilizing the pit at the Hanford Site 305 Building. The setup simulated the configuration expected in waste tanks (Efferding 1992a). The view of the IR scanner was directed downward onto three locations, as follows:

- Directly under the scanner at $2.7 \mathrm{~m}(8.9 \mathrm{ft})$ below

- At a $60^{\circ}$ angle of incidence or 6 to $7 \mathrm{~m}$ (20 to $23 \mathrm{ft}$ ) from scanner

- At an $80^{\circ}$ angle of incidence or $10 \mathrm{~m}$ (33 ft) from scanner.

The simulated waste surfaces were in $1.2 \times 1.2-\mathrm{m}(4 \times 4-\mathrm{ft})$ wooden forms, or vats, into which a simulant of urea fertilizer, sugar, and water was cast to form a flat area, a mound, and a depression in each vat. This simulant was chosen because its low thermal conductivity and surface texture is similar to saltcake. Groups of five thermocouples, at different depths, were embedded in 
WHC-SD-WM-TRP-218

Rev. 0

the waste simulations along with electrical heaters. Temperatures at the surface could be estimated by extrapolating the temperature-depth curves. The temperature on the surface was needed for comparison with IR radiometric readings.

\subsubsection{Results of System Performance Test}

Both vats of simulant were measured at a $60^{\circ}$ angle of incidence. Only one vat was measured at $0^{\circ}$ and $80^{\circ}$. Figure $3-3$ shows a thermogram of the test vats at the $60^{\circ}$ angle of incidence. The view is rotated $90^{\circ}$ so the temperatures can be read. The farther vat is to the left and the nearer to the right. The vats are both the same size; however, the left vat appears smaller and distorted because of the viewing angle and distance. The four band heaters are below the surface of the simulant. The four bright strips of yellow that run the length of the vats are evidence of the heat being generated by the heaters. Where the bright strips are interrupted is the mound where the simulant is thicker and less energy as heat is emitted. In Table 3-1 the surface temperatures are compared with the IR radiometric readings. Two readings were given for each of the surface locations at the $60^{\circ}$ angle of incidence location. The IR radiometric readings were taken of the surface above the thermocouple groups. The smallest difference between the thermocouple reading and the infrared reading was $0{ }^{\circ} \mathrm{C}\left(0.1^{\circ} \mathrm{F}\right)$, and the largest was $2.0^{\circ} \mathrm{C}\left(3.7^{\circ} \mathrm{F}\right)$. These accuracy ranges are dependent on the extreme surface conditions of taking measurements on a mound or depression.

\subsubsection{Validation of System Performance Test}

The system performance test was done as impact level 3 (WHC 1988 and WHC 1991). AlT thermocouple calibrations were up-to-date and recorded as required by WHC procedures.

\subsubsection{Conclusions}

These data suggest that the IR radiometric measurements do not differ from the true temperature by more than $\pm 2.0^{\circ} \mathrm{C}\left( \pm 3.7^{\circ} \mathrm{F}\right.$ ) within $2-$ sigma confidence limits. This accuracy is conservative since it depends on the extreme temperature effects of the surface geometry. Temperature sensitivity under in-tank conditions is with in $\pm 0.28^{\circ} \mathrm{C}\left( \pm 0.50^{\circ} \mathrm{F}\right)$. It can be theorized that an area could be hidden from the scanner by the surface geometry. If a hot spot is in this area, only part of the pattern may be seen. The deployment of the infrared scanner should be accompanied by photographs of the interior to ensure that all the essential areas are visible to the infrared scanner.

\subsection{ACCEPTANCE TEST}

\subsubsection{Description of Acceptance Test}

The IR imaging system was tested (Griffin 1992) to verify that the electrical and mechanical components operated as required to perform an in-tank test. The specific components tested were the pan and tilt unit, the purge system, and the contamination control bag. 
Figure 3-3. A Thermogram of the Test Waste Simulations at the $60^{\circ}$ Angle of Incidence.

\section{I.R. Scan of Two Vats of Simulated Waste}

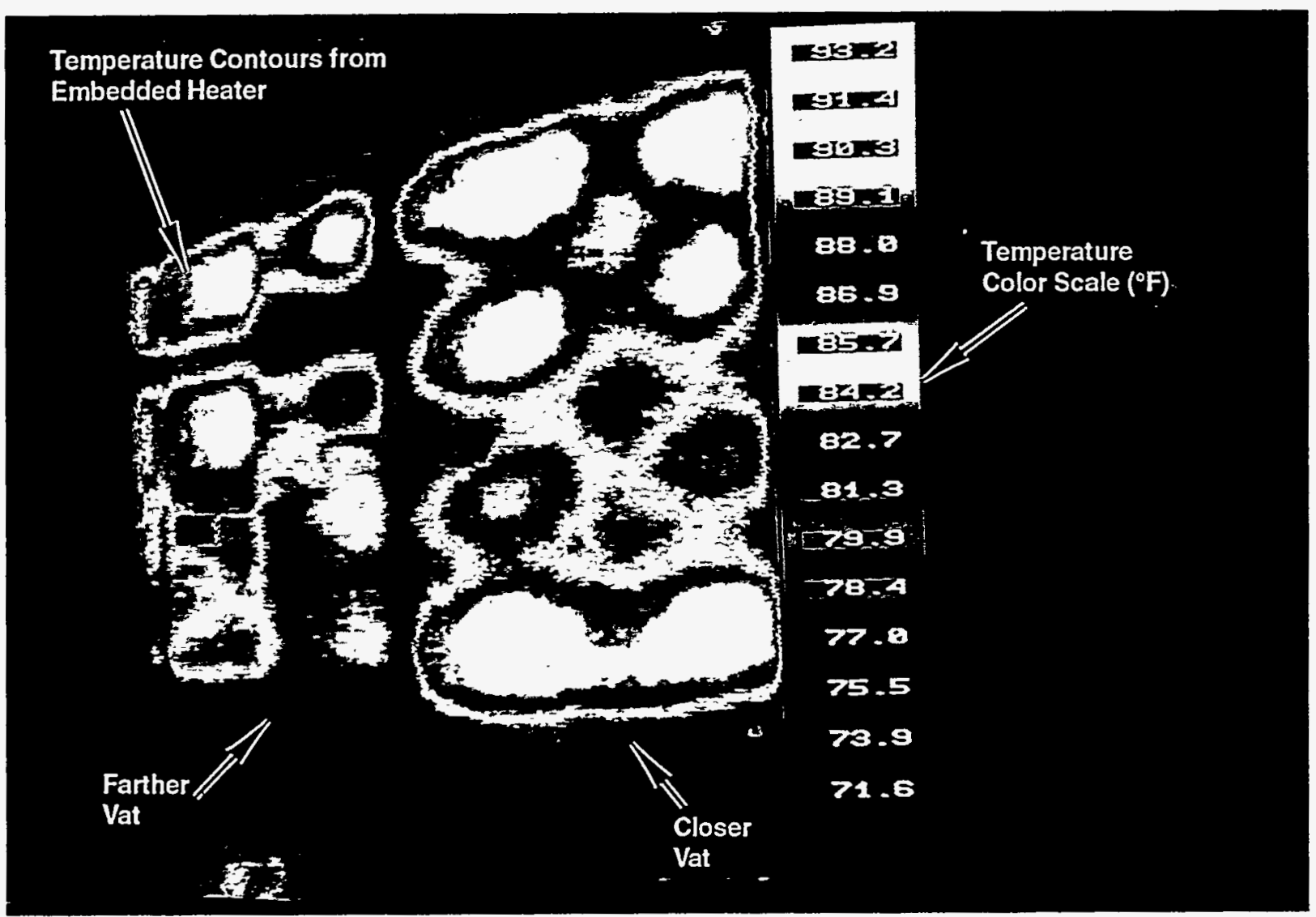


Table 3-1. Calibration of Infrared Scanner.

\begin{tabular}{|c|c|c|c|}
\hline Location & Thermocouple & IR scanner & Difference \\
\hline $\begin{array}{l}\text { Vertically below } \\
\text { on a mound }\end{array}$ & $30.4^{\circ} \mathrm{C}\left(86.8^{\circ} \mathrm{F}\right)$ & $30.3^{\circ} \mathrm{C}\left(86.5^{\circ} \mathrm{F}\right)$ & $0.1^{\circ} \mathrm{C}\left(0.3^{\circ} \mathrm{F}\right)$ \\
\hline $\begin{array}{l}\text { Vertically below } \\
\text { in a depression }\end{array}$ & $32.6{ }^{\circ} \mathrm{C}\left(90.6^{\circ} \mathrm{F}\right)$ & $31.9^{\circ} \mathrm{C}\left(89.5^{\circ} \mathrm{F}\right)$ & $0.7^{\circ} \mathrm{C}\left(1.1^{\circ} \mathrm{F}\right)$ \\
\hline $\begin{array}{l}60^{\circ} \text { angle of } \\
\text { incidence on a } \\
\text { mound (Vat I) }\end{array}$ & $31.8^{\circ} \mathrm{C}\left(89.3^{\circ} \mathrm{F}\right)$ & $29.8^{\circ} \mathrm{C}\left(85.6^{\circ} \mathrm{F}\right)$ & $2.0^{\circ} \mathrm{C}\left(3.7^{\circ} \mathrm{F}\right)$ \\
\hline $\begin{array}{l}60^{\circ} \text { angle of } \\
\text { incidence in a } \\
\text { depression (Vat } 2 \text { ) }\end{array}$ & $32.2^{\circ} \mathrm{C}\left(90.0^{\circ} \mathrm{F}\right)$ & $31.2^{\circ} \mathrm{C}\left(88.2^{\circ} \mathrm{F}\right)$ & $1.0^{\circ} \mathrm{C}\left(1.8^{\circ} \mathrm{F}\right)$ \\
\hline $\begin{array}{l}60^{\circ} \text { angle of } \\
\text { incidence on a } \\
\text { mound (Vat I) }\end{array}$ & $31.4^{\circ} \mathrm{C}\left(88.6^{\circ} \mathrm{F}\right)$ & $30.5^{\circ} \mathrm{C}\left(86.9^{\circ} \mathrm{F}\right)$ & $0.9^{\circ} \mathrm{C}\left(1.7^{\circ} \mathrm{F}\right)$ \\
\hline $\begin{array}{l}60^{\circ} \text { angle of } \\
\text { incidence in a } \\
\text { depression (Vat 2) }\end{array}$ & $36.9^{\circ} \mathrm{C}\left(98.4^{\circ} \mathrm{F}\right)$ & $35.3^{\circ} \mathrm{C}\left(95.6^{\circ} \mathrm{F}\right)$ & $1.6^{\circ} \mathrm{C}\left(2.8^{\circ} \mathrm{F}\right)$ \\
\hline $\begin{array}{l}80^{\circ} \text { angle of } \\
\text { incidence on a } \\
\text { mound }\end{array}$ & $29.8^{\circ} \mathrm{C}\left(85.7^{\circ} \mathrm{F}\right)$ & $29.8^{\circ} \mathrm{C}\left(85.6^{\circ} \mathrm{F}\right)$ & $0.0^{\circ} \mathrm{C}\left(0.1^{\circ} \mathrm{F}\right)$ \\
\hline $\begin{array}{l}80^{\circ} \text { angle of } \\
\text { incidence in a } \\
\text { depression }\end{array}$ & $30.3^{\circ} \mathrm{C}\left(86.6^{\circ} \mathrm{F}\right)$ & $30.2^{\circ} \mathrm{C}\left(86.3^{\circ} \mathrm{F}\right)$ & $0.1^{\circ} \mathrm{C}\left(0.3^{\circ} \mathrm{F}\right)$ \\
\hline
\end{tabular}

\subsubsection{Summary of Acceptance Test}

The limits of rotation and tilt were tested on the pan and tilt unit. The unit was also tested for default position on loss of power or hydraulics. The purge gas cooling system was operated during testing of other parameters to establish real-time gas usage. The contamination control bag was tested for interference with the pan and tilt operation and for removal from the riser.

\subsubsection{Results of Acceptance Test}

The pan rotation was $0^{\circ}$ to $357^{\circ}$. The tilt moved between $0^{\circ}$ and $86^{\circ}$. The unit went to default position on loss of power or hydraulics. The cooling system operated at the specified flow rate for 1 hour 37 minutes. The contamination control bag did not interfere with the operation. 
WHC-SD-WM-TRP-218

Rev. 0

\subsubsection{Validation of Acceptance Test}

The acceptance test was documented at impact level 3 (WHC 1988 and WHC 1991). The test engineer and a Quality Control representative verified and signed a 11 data sheets and exceptions. All equipment items requiring calibration, such as torque wrenches, were verified according to WHC procedures prior to sign-off.

\subsubsection{Conclusions}

The IR imaging system was acceptable. The pan unit was required to rotate between $0^{\circ}$ to $359^{\circ}$ rather than $0^{\circ}$ to $357^{\circ}$; however, the view overlaps at each end of the rotation, so this was accepted. The tilt was required to view at $90^{\circ}$, rather than $86^{\circ}$, but because of view overlap the entire tank can still be seen, so this was accepted. Neither the contamination control bag or the purge gas cooling had any exceptions.

\subsection{SUMMARY OF LABORATORY TESTING} follows:

The results of the laboratory tests on the IR imaging system are as

- Temperature sensitivity--Under ideal conditions, $\pm 0.15{ }^{\circ} \mathrm{C}( \pm$ $\left.0.27{ }^{\circ} \mathrm{F}\right)$. In-tank conditions, $\pm 0.28{ }^{\circ} \mathrm{C}\left( \pm 0.50^{\circ} \mathrm{F}\right)$. (See Section 3.1 and Section 3.6.)

- Emissivity of ferrocyanide waste simulants--0.94 to 0.95 . A $60^{\circ}$ angle of incidence does not affect radiometric readings on the surfaces measured (see Section 3.2).

- Atmospheric attenuation--Negligible (approximately $2 \%$ within the temperature range of the tank). The practical maximum distance for viewing in the tank dome space is $14 \mathrm{~m}$ ( $46 \mathrm{ft}$ ). Further work is needed to quantify the effects of higher than $50 \%$ relative humidity (see Section 3.3).

- Expected life in radiation field--1000R (Messenger and Ash 1986). No effects were noticed in the radiometric readings during operation in a gamma radiation field (see Section 3.4).

- Ambient temperature operation--The internal temperature of the camera must be kept at $+4.0^{\circ} \mathrm{C}\left(+7.2^{\circ} \mathrm{F}\right)$ of the ambient temperature for accurate readings. The nitrogen flow rate required to achieve this is $0.7 \pm 0.1 \mathrm{~L} / \mathrm{sec}\left(1.5 \pm 0.2 \mathrm{ft}^{3} / \mathrm{min}\right)$ (see Section 3.5).

- Temperature accuracy--Under ideal conditions, $\pm 0.50{ }^{\circ} \mathrm{C}\left( \pm 0.90{ }^{\circ} \mathrm{F}\right)$. Under in-tank conditions, $\pm 2.0^{\circ} \mathrm{C}\left( \pm 3.7^{\circ} \mathrm{F}\right)$. (See Section 3.1 and Section 3.6.)

- Acceptance test--The system was accepted (see Section 3.7). 
WHC-SD-WM-TRP-218

Rev. 0

This page intentionally left blank. 
WHC-SD-WM-TRP-218

Rev. 0

\subsection{FIELD TEST OF INFRARED IMAGING SYSTEM}

The 241-S-110 Waste Tank Test was developed as a field test to evaluate the utility of the IR imaging system for obtaining waste surface temperature measurements in ferrocyanide waste tanks. Tank $241-S-110$ is not a

ferrocyanide waste tank, however.

\subsection{DESCRIPTION OF TEST IN TANK 24I-S-110}

The field test began when the IR imaging system was installed in Tank 241-S-110 just below the surface of the dome (Figure 4-1). IR scanning of the tank began facing due south at a tilt angle of $20^{\circ}$. Starting again at due south, subsequent images were taken and recorded on videotape at 20,35, 50,70 and 90 degrees. After panning the scanner to both stops and at all required tilt angles, the tank scan was complete.

\subsection{SUMMARY OF TEST IN TANK 241-S-110}

Installation into the tank takes approximately four hours, not counting system warm up. The system was tested for functionality during warm-up (approximately $30 \mathrm{~min}$ ). Scanning of the tank was completed in $1.5 \mathrm{hr}$. A videotape of the IR scan was reviewed by WHC engineers to verify retrieval of data and the quality of the recording (Mailhot 1991). The infrared images stored in the TIMS accounted for approximately $90 \%$ coverage of the total surface area. The areas not scanned are indicated in Figure 4-2. The rotational feedback failed on the pan unit due to interference with the contamination control bag, so the pan and tilt unit was operated manually. This method of operation is not as accurate for placement. The unscanned locations in Figure 4-2 were determined by known landmarks within the waste tank.

A pan of the abandoned pipe located beneath Riser 7 demonstrated that the pan was not reaching the clockwise and counterclockwise limit stops. This accounts for the southern area not being covered in the scan. Other areas not covered resulted from operator error. After this procedure was completed, the scanner assembly was pulled up into the riser $1.1 \mathrm{~m}(3.5 \mathrm{ft})$, but not out of the tank, because of the limited working time left for the personnel on the shift. The scanner was pulled completely out the next morning and checked for radioactive contamination. No smearable radioactive contamination was present.

Based on the effectiveness of the shielding in the housing and an expected life use for 24 tanks, the maximum radiation dose rate to the scanner was estimated to be on the order of $20 \mathrm{R} / \mathrm{hr}$ (Morford 1991). The maximum dose expected for the electronics as a result of the 3.5-hr period the scanner was in the tank vapor space would be approximately $70 \mathrm{R}$. The radiation dose rate at the opening of Riser 7 was measured at $180 \mathrm{mR} / \mathrm{hr}$; this is the dose rate estimated for the interior of the riser. Therefore, it is estimated that, for 


\author{
WHC-SD-WM-TRP-218 \\ Rev. 0
}

Figure 4-1. Placement of Infrared Scanner in Tank 241-S-110.

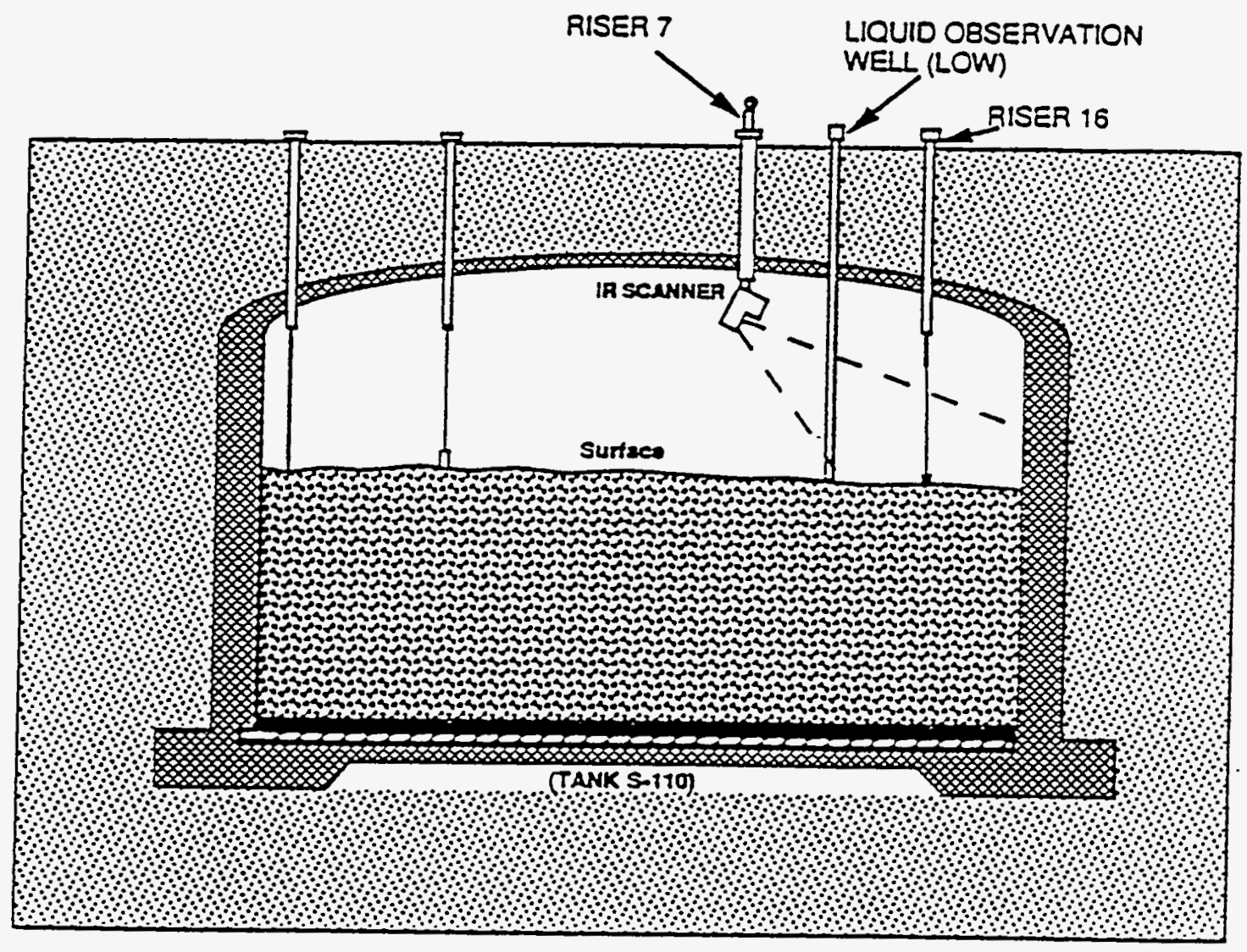


Figure 4-2. Scanned Areas of Tank 241-S-110.

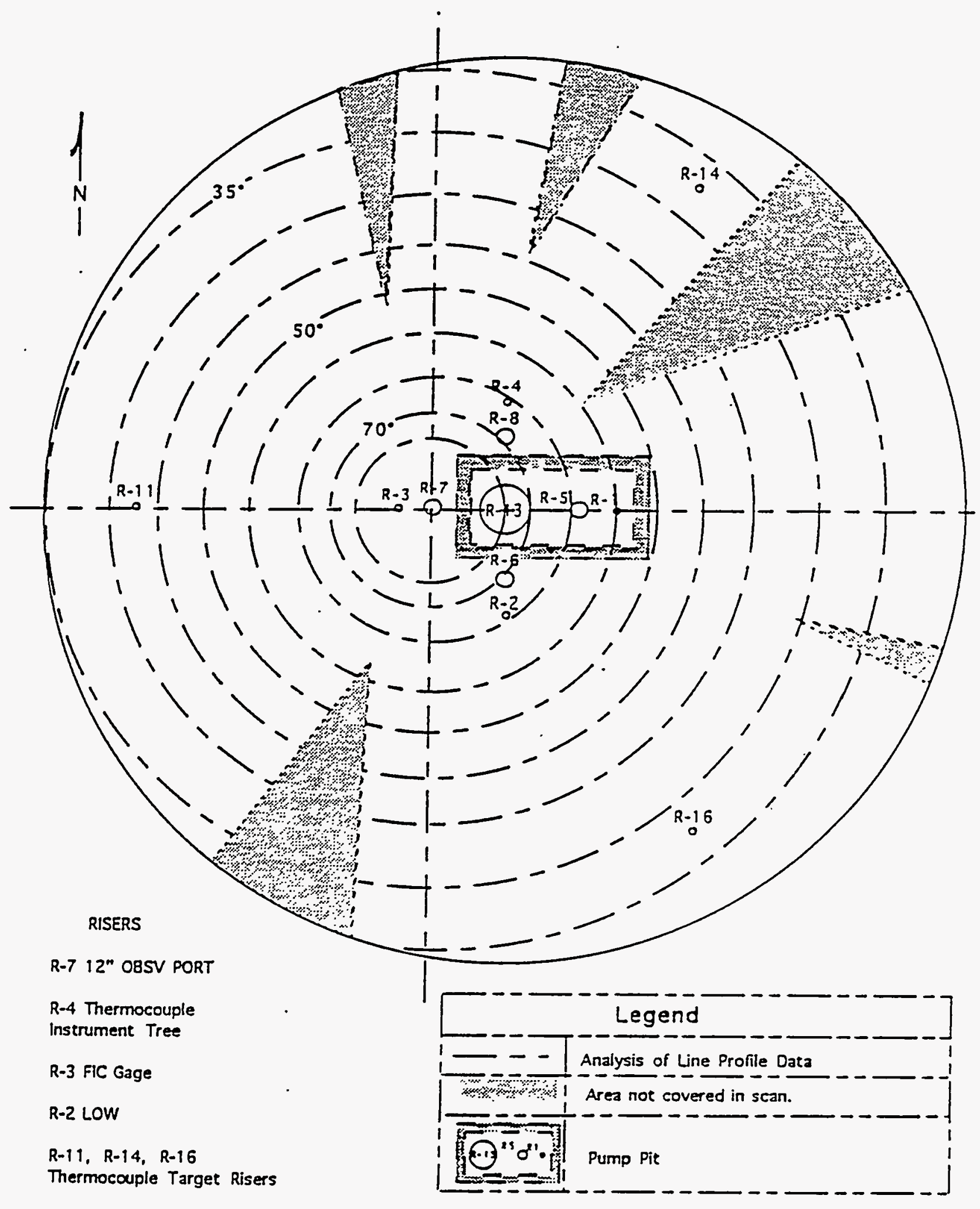


WHC-SD-WM-TRP-218

Rev. 0

the time the IR scanner was in the riser, the dose would be $4 R$. Thus the maximum expected total dose for the scanner electronics during the entire scan of 241-S-110 is estimated to be $74 \mathrm{R}$.

Based on the projected radiation tolerance of the IR scanner, another 13 tanks could be scanned with this equipment (assuming similar dose rates). If the efficiency of future in-tank procedures could be doubled, as many as 25 tanks could be scanned with the IR equipment.

\subsection{RESULTS AND OBSERVATIONS OF TEST IN TANK 241-S-110}

Analysis of the thermograms taken in 241-S-110 (Efferding 1992b) shows that no hot spot characteristics can be found on the surface of the waste. None were expected. The analysis did show that the IR imaging system could find thermal contours with a $\pm 0.28{ }^{\circ} \mathrm{C}\left( \pm 0.50^{\circ} \mathrm{F}\right)$ sensitivity over a range of 20 to $54.4^{\circ} \mathrm{C}\left(68\right.$ to $\left.130^{\circ} \mathrm{F}\right)$ on the waste surface. The analys is required approximately one week to complete.

The results are summarized in Table 4-1 and shown in the thermogram of Tank 241-S-110 (Figure 4-3). Figure $4-3$ is a black and white montage of 64 thermal photographs that were made of the tank. This figure shows relatively warm areas as lighter gray to white. Relatively cool areas are darker gray. According to radiometric measurement, the difference in temperature in the scan of tank $241-\mathrm{S}-110$ was $4.1{ }^{\circ} \mathrm{C}\left(7.5^{\circ} \mathrm{F}\right)$. The highest temperature reading was $29.4^{\circ} \mathrm{C}\left(85.0^{\circ} \mathrm{F}\right)$. The lowest temperature reading was about $25.3^{\circ} \mathrm{C}\left(77^{\circ} 5^{\circ} \mathrm{F}\right)$.

A color-enhanced montage of the tank 241-S-110 thermogram is presented in Figure 4-4. It should be emphasized, however, that the computer monitor for the IR system (see Section 2.0) provides greater detail than either of these figures.

Table 4-1. Summary of System Performance.

\begin{tabular}{|l|c|c|c|}
\hline & $\begin{array}{c}\text { Vendor specification } \\
\text { value }\end{array}$ & $\begin{array}{c}\text { Ideal condition } \\
\text { value }\end{array}$ & $\begin{array}{c}\text { In-tank } \\
\text { value }\end{array}$ \\
\hline $\begin{array}{l}\text { Temperature } \\
\text { accuracy }\end{array}$ & $\pm 4.0^{\circ} \mathrm{C}$ & $\pm 0.50^{\circ} \mathrm{C}$ & $\pm 2.0^{\circ} \mathrm{C}$ \\
\hline $\begin{array}{l}\text { Temperature } \\
\text { sensitivity }\end{array}$ & $\left.-2^{\circ} \mathrm{F}\right)$ & $\left( \pm 0.90^{\circ} \mathrm{F}\right)$ & $\left( \pm 3.7^{\circ} \mathrm{F}\right)$ \\
\hline
\end{tabular}

The temperature of the waste approximately $.6 \mathrm{~m}(2 \mathrm{ft})$ below the surface was approximately $19{ }^{\circ} \mathrm{C}\left(35^{\circ} \mathrm{F}\right)$ higher than the surface temperature.

Therefore, any equipment penetrating through the surface from the waste indicated higher temperatures than the surface. This was due to conduction of the heat from the higher-temperature waste below the surface. 


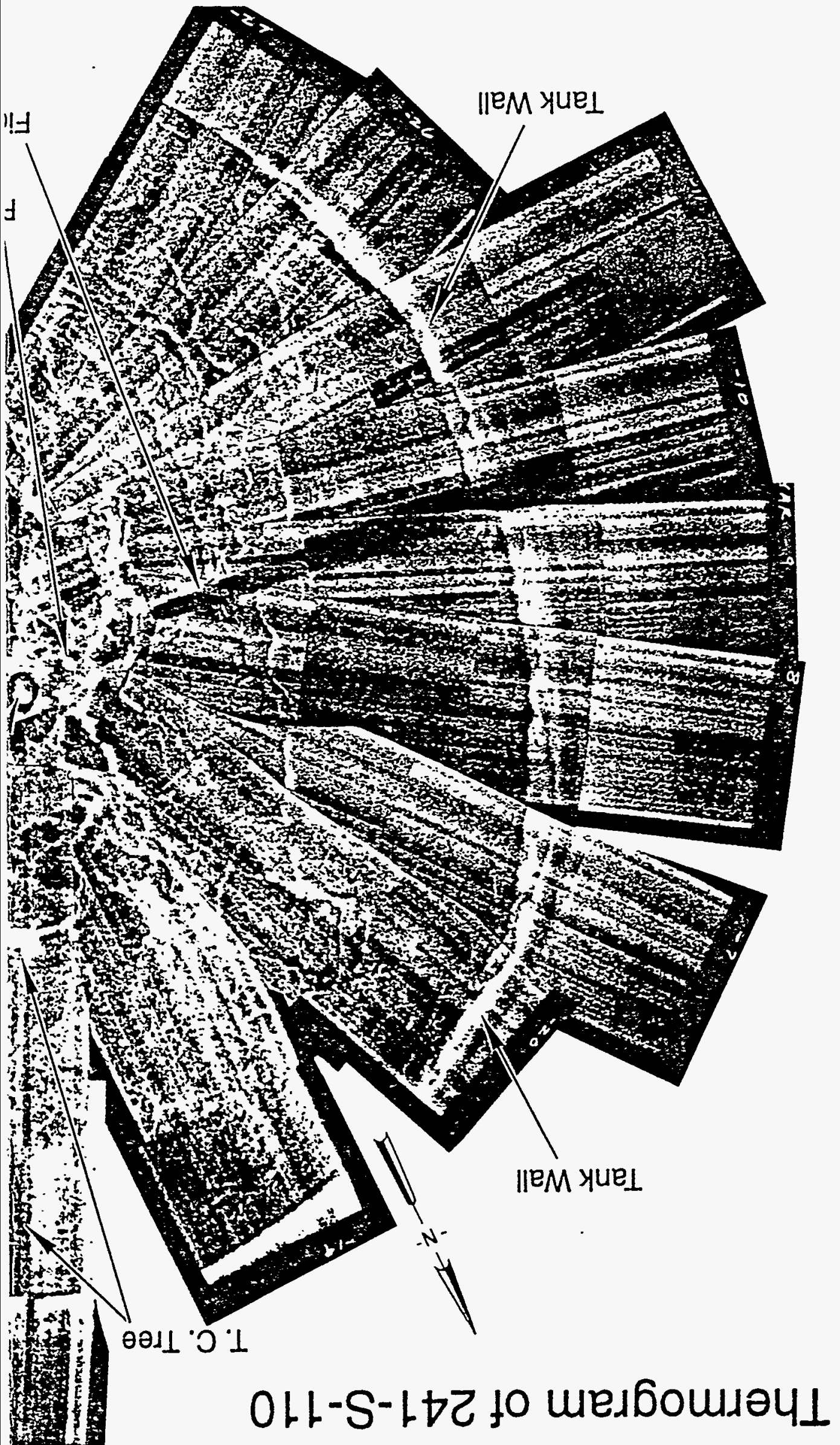




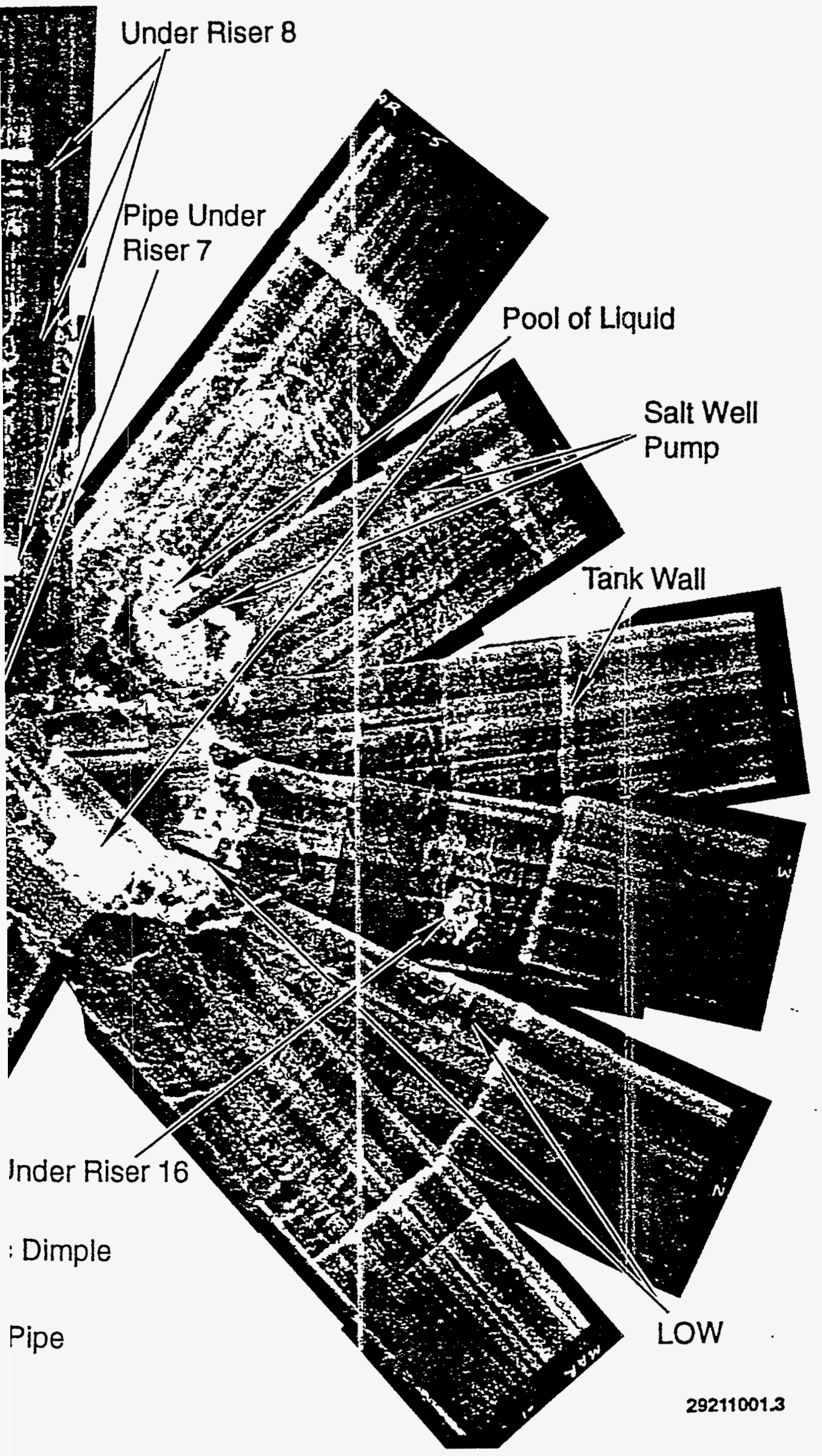

Figure 4-3. Thermogram of Tank 241-S-1 
Figure 4-4. Color-Enhanced Thermogram of Tank 241-S-110.

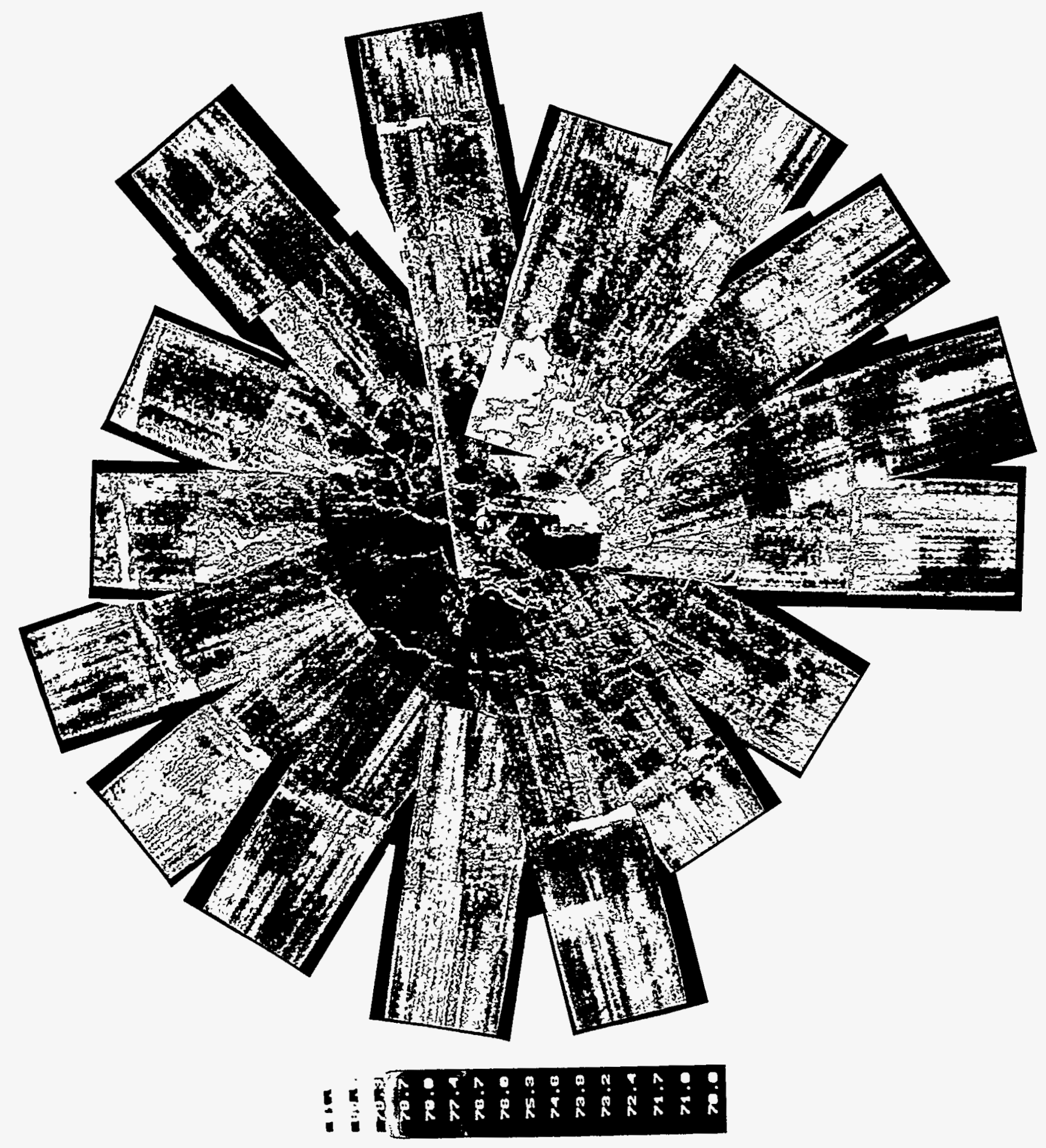


WHC-SD-WM-TRP-218

Rev. 0

Various in-tank features can be distinguished by their local temperature variations. The surface of the waste can be seen in the center of the thermogram. The intersection of the tank wall and the waste is marked by the white curved strip on the thermal photographs, indicating conduction of heat from the higher-temperature waste under the surface at the tank wall. Immediately under the scanner, protruding from the waste, is a length of pipe. The radiometric measurement of the pipe temperature was $28.9{ }^{\circ} \mathrm{C}\left(84.0^{\circ} \mathrm{F}\right)$. This is one of the warmest places found. It is believed that the pipe is conducting heat from the lower waste mass, which raises the observed temperature looking into the pipe. Numerous cracks can be seen in the surface crust; these are indicated as the white (hotter) areas.

A short distance west of the pipe is the FIC dimple. This is a depression generated by the FIC level detection gage during years of operation. The FIC tape passes through a pipe for a distance from the riser to near the surface. The pipe is visible as a darker (10w-temperature) object "pointing" to the dimple from the west. The location where the FIC pipe crosses the image of the surface-to-tank wall interface can be seen as an interruption in the tank wall circle.

North of the length of pipe, the TC tree can be seen extending from a warm region on the surface to, and past, the tank wall-to-waste surface interface. A pipe from Riser 8, near the TC tree, forms a warm region just south of the TC tree spot. These warm regions are the result of the metallic pipe of the TC tree conducting heat from the warm, liquid waste material that is below the surface saltcake. Southwest of the length of pipe is a pool of 7 iquid. The radiometric measurement of the edge is $26.7^{\circ} \mathrm{C}\left(80.0^{\circ} \mathrm{F}\right)$. Under riser 16 the warmest region in the tank is found in the center of a depression, with a temperature of $28.4^{\circ} \mathrm{C}\left(84.0^{\circ} \mathrm{F}\right)$. This is due to the insulating effect of the walls of the depression on its center.

The liquid observation well (LOW) is just visible south of the length of pipe. The coolest regions on the waste surface (west of the length of pipe, and al so in the region of the pool of 1 iquid) are about $25.3{ }^{\circ} \mathrm{C}\left(77.5{ }^{\circ} \mathrm{F}\right)$. Most of the other regions are about $26.7^{\circ} \mathrm{C}\left(80.0^{\circ} \mathrm{F}\right)$. Cool regions are believed to have the greatest saltcake cover. A thorough explanation of the details of the observed temperature patterns is found in Efferding (1992b). No pattern which might indicate the existence of a subsurface hot spot (similar to Figures 1-1 and 1-2) is evident.

\subsection{VALIDATION OF TEST IN TANK 241-S-110}

The field test of the IR imaging system was documented as impact level 3 (WHC 1991 and WHC 1988). Through WHC Quality Assurance, Quality Control hold points were established. Quality Control personnel were present during testing.

\subsection{CONCLUSIONS OF TANK 241-S-110 TEST}

The IR imaging system performed satisfactorily. The final results were analyzed by the WHC ThermaT HydrauTics Analysis group to determine the 
WHC-SD-WM-TRP-218

Rev. 0

potential of the IR imaging system for detecting hot spots located within tank waste (Efferding 1992b). The IR imaging system can determine hot spots as defined in McLaren (1991) with a $\pm 0.28{ }^{\circ} \mathrm{C}\left( \pm 0.50{ }^{\circ} \mathrm{F}\right.$ ) sensitivity (Efferding 1992b). The durability of the scanner mechanism cannot be addressed until. the unit has completed a full cycle of tanks. This is expected to be 12 to 25 additional waste tanks, depending on the efficiency of future procedures and the dose rates encountered.

A calibrated thermocouple was placed (one each) in Risers 11, 14, and 16 of tank 241-S-110 before the IR imaging activities (see Table 4-2). The accuracy of these thermocouples is questionable due to placement difficulties (i.e., it is uncertain whether they made good contact with the waste). However, the thermocouple temperatures are in reasonable agreement with the IR measurements taken of the same area and provide a double-check on the system. These thermocouples did not replace the accuracy calibration already done for the IR scanner (see Sections 3.1 and 3.6). The IR surface scan was analyzed for temperature variations for determining the capability of the system to find hot spots within a ferrocyanide waste tank (Efferding 1992b).

Table 4-2. Thermocouple Reading of Waste.

\begin{tabular}{|c|c|c|}
\hline Riser & Thermocouple reading & IR scanner reading \\
\hline 11 & $24.8^{\circ} \mathrm{C}\left(76.6^{\circ} \mathrm{F}\right)$ & $25.6^{\circ} \mathrm{C}\left(78.0^{\circ} \mathrm{F}\right)$ \\
\hline 14 & $24.4^{\circ} \mathrm{C}\left(75.9^{\circ} \mathrm{F}\right)$ & $25.6^{\circ} \mathrm{C}\left(78.0^{\circ} \mathrm{F}\right)$ \\
\hline 16 & $28.9^{\circ} \mathrm{C}\left(84.1^{\circ} \mathrm{F}\right)$ & $28.9^{\circ} \mathrm{C}\left(84.0^{\circ} \mathrm{F}\right)$ \\
\hline
\end{tabular}

Although there is no data on the in-tank humidity, engineering judgment is that the humidity of this type of tank is less than the environment's humidity. The average RH at the Hanford Site is $50 \%$. 
WHC-SD-WM-TRP-218

Rev. 0

This page intentionally left blank. 
WHC-SD-WM-TRP-218

Rev. 0

\subsection{SUMMARY}

\subsection{OBSERVATIONS AND RESULTS}

Under in-tank conditions, the temperature accuracy of the IR system was demonstrated to be $\pm 2.0^{\circ} \mathrm{C}\left( \pm 3.6{ }^{\circ} \mathrm{F}\right)$; temperature sensitivity was observed to be $\pm 0.28{ }^{\circ} \mathrm{C}\left( \pm 0.50^{\circ} \mathrm{F}\right)$ (see Section 3.6). Under laboratory conditions, humidity affected temperature readings by no more than $\pm 2.2{ }^{\circ} \mathrm{C}$ (see

Section 3.3); system accuracy was maintained at all angles of incidence up to $60^{\circ}$. The in-field test of tank 241-5-110 provided confirmation that the infrared imaging system can perform in a tank environment.

Currently, the characteristics of the ferrocyanjde tanks are being studied to determine the credibility of hot spots occurring in the waste. Results of these studies are scheduled to be complete in FY 1993.

\subsection{CONCLUSIONS AND RECOMMENDATIONS}

The scope of this effort was to characterize the performance of IR imaging technology for application in determining thermal patterns indicating hot spots in Hanford Site ferrocyanide tanks. The infrared imaging system, as designed and tested, has shown the capability to detect and provide data to generate a reliable surface temperature contour map. Specifically, the IR imaging system:

- Operated successfully in a non-Watchlist tank (241-S-110) as a field test

- Measured surface temperatures in a tank and proved capable of identifying temperature contours of $\pm 0.28^{\circ} \mathrm{C}\left( \pm 0.50^{\circ} \mathrm{F}\right)$

- Demonstrated that in-tank handling equipment could be designed, fabricated, and operated

- Confirmed that in-tank IR imaging can be accomplished within ALARA, safety, and other Tank Farm operating criteria.

Detection limits are fine enough (as shown in Section 3.6) that a hot spot with temperatures high enough to be of concern will create a detectable surface temperature pattern in the majority of the ferrocyanide tanks (see Sections 1.3.1 and 1.3.2). The IR imaging system also has demonstrated the capacity to determine a worst-case hot spot that would be reflected by temperature patterns observed on the surface of the waste. The waste depths in 3 of the 24 tanks are deeper than the tank on which the temperature pattern was modeled, and some tanks may have limited access (see Section 3.3.5). On the basis of this data, the IR imaging system is a useful technology for initial evaluation and assessment of hot spots in the majority of ferrocyanide waste tanks at the Hanford Site. The system will not allow an exact hot spot size and temperature determination, but will provide the necessary information to determine the worst-case hot spot causing the temperature pattern detected. 
WHC-SD-WM-TRP-218

Rev. 0

This page intentionally left blank. 
WHC-SD-WM-TRP-218

Rev. 0

\subsection{REFERENCES}

Air Force Geophysics Laboratory, 1990, PCTRAN 7 - Personal Computer Version of the LOWTRAN 7 Atmospheric Mode], Version 2, ONTAR Corporation, Cambridge, Massachusetts.

Alstad, Allen T., 1988, Riser Configuration Document for Single-Shell Waste Tanks, WHC-SD-RE-TI-053, Rev. 7, Westinghouse Hanford Company, Richland, Washington.

Burger, L. L. and Scheele, R. D., 1991, The Reactivity of Cesium Nickel Ferrocyanide to Nitrate and Nitrite Salts -- A Status Report, PNL-7550, Pacific Northwest Laboratory, Richland, Washington.

Efferding, L. E., 1992a, Infrared Scanner Parametric Thermal Sensitivity Test, WHC-SD-WM-ER-154, Rev. 0, Westinghouse Hanford Company, Richland, Washington.

Efferding, L. E., 1992b, Surface Temperature Data Records and Interpretation of Infrared Scanning of Tank S-110/N24C3, WHC-SD-WM-ER-156, Rev. 0, Westinghouse Hanford Company, Richland, Washington.

Griffin, T. E., 1992, Acceptance Test Report for a Waste Tank Infrared Imaging System, WHC-SD-WM-ATR-027, Rev. 0, Westinghouse Hanford Company, Richland, Washington.

Hanlon, B. M., 1992, Tank Farm Surveillance and Waste Status Summary Report for January 1992, WHC-EP-0182-46, Westinghouse Hanford. Company, Richland, Washington.

Mailhot, R. B., 1991, Test Procedures for Infrared Imaging System, WHC-SD-WN-TC-021, Rev. 0, Westinghouse Hanford Company, Richland, Washington.

Mailhot, R. B., 1992, Non-Watch List Waste Tank Test P7an/Procedure, WHC-SD-WM-TP-129, Rev. 0, Westinghouse Hanford Company, Richland, Washington.

Mailhot, R. B. and K. L. Morris, 1992, Ferrocyanide Waste Tank Infrared Imaging System Requirements, WHC-SD-WM-DB-007, Rev. 0, Westinghouse Hanford Company, Richland, Washington.

Mailhot, R. B. and M. 0. Rankin, 1992, Engineering Test Report for the Ferrocyanide Waste Tank Infrared Imaging System, WHC-SD-WM-TRP-067, Rev. 0, Westinghouse Hanford Company, Richland, Washington.

McLaren, J. M., 1991, Single-She11 Tank 241-BY-104 Therma7-Hydraulic Analysis, WHC-EP-0521, Rev. 0, Westinghouse Hanford Company, Richland, Washington.

Messenger, G. C., and Ash, M. S., 1986, The Effects of Radiation on Electronic Systems, Van Nostrand Reinhold Co., New York, New York. 